Bringing Supermarkets into Food Deserts: An Analysis of Retail Intervention Policies John Fife

PA 5598C, Independent Study

University of Missouri - Kansas City

Spring 2012 


\begin{abstract}
This paper looks at policy efforts used to address the food access issues plaguing urban areas commonly referred to as food deserts. The efforts are framed as retail intervention policies, and the paper follows a structured inquiry to assess retail intervention policy effectiveness in bringing supermarkets in underserved urban areas. Through five case studies (Liberty City, Pennsylvania, Illinois and Chicago, New Orleans, and Kansas City) this paper examines the creation and use of several different retail intervention policies. Each case study presents the conditions predicating the need to improve food access and the policy instruments used to address the issues. The paper assesses the policies based on seven features: strategy components, funding stream, viability, duration, scope, cost-effectiveness, and repeatability. The analysis compares the cases to determine overall policy efficacy and impact. The paper makes several conclusions regarding retail intervention policies. Corporation-initiated efforts to open stores indicate market-expansion rather than actual policy. While TIF (tax increment financing) polices can be effective for financing and land development in urban revitalization projects, the market analyses used in TIF models are not appropriately designed to understand and measure the potential success of supermarket projects. A specifically designed food financing policy such as FFFI needs to have a community-based food-advocacy group, sufficient start-up funds, and a capable CDFI (community development financial institution) in order to sustain program operations and support successful supermarket projects.
\end{abstract}




\section{Bringing Supermarkets into Food Deserts: An Analysis of Retail Intervention Policies}

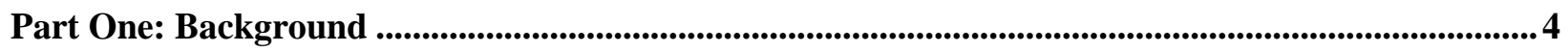

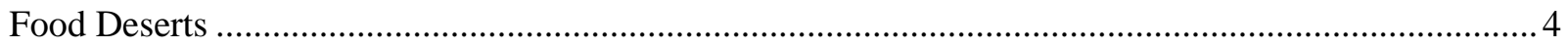

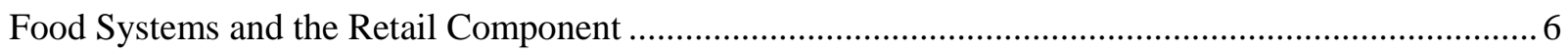

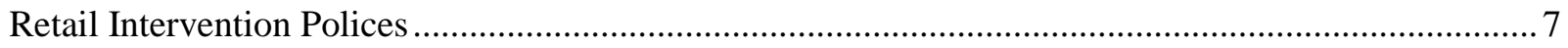

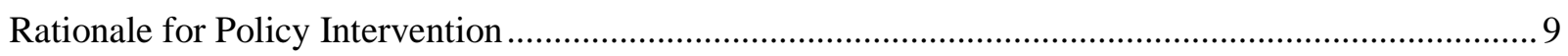

Part Two: Methodology ............................................................................................................................................... 10

Part Three: Recent Food Initiatives and Policies Overview ..............................................................11

Part Four: Case Studies, Past and Present Policy Efforts............................................................................. 12

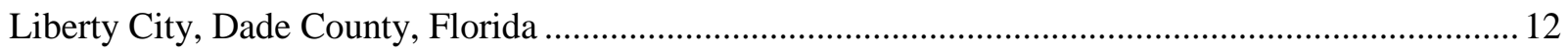

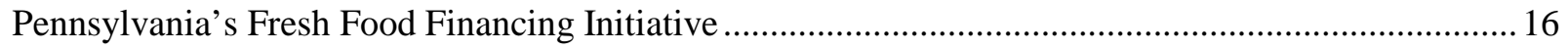

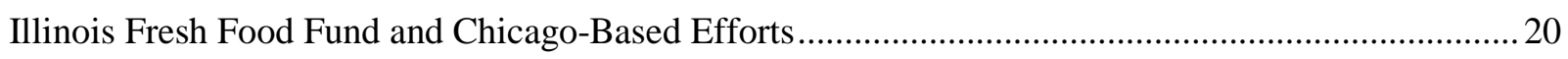

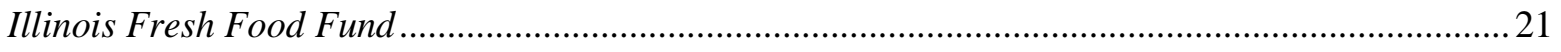

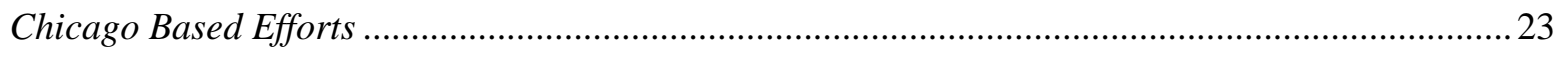

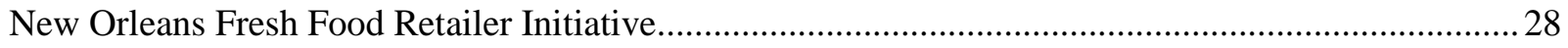

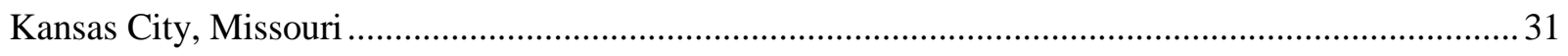

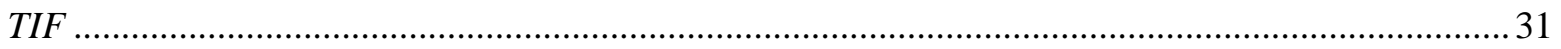

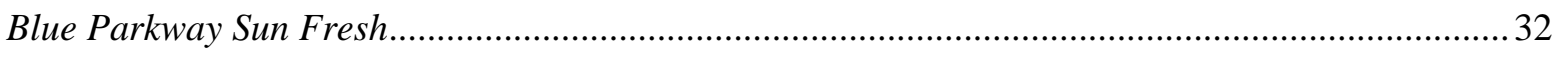

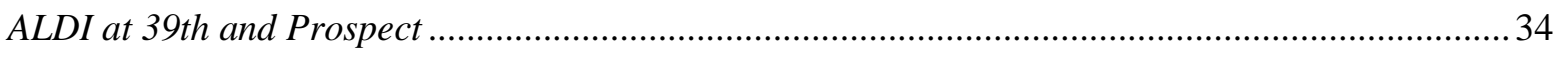

Truman Medical Center Community Grocery Store ...................................................................... 36

Part Five: Meta-Analysis, Policy Comparison, Repeatability, Effectiveness ........................................ 38

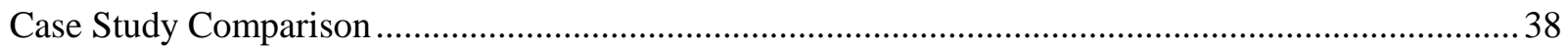

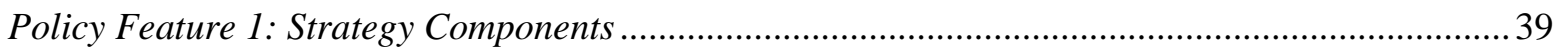

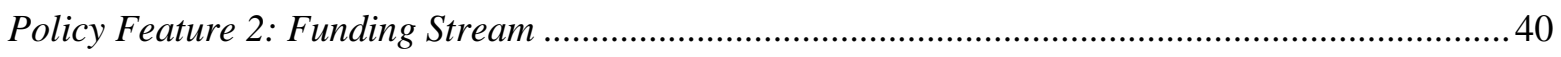

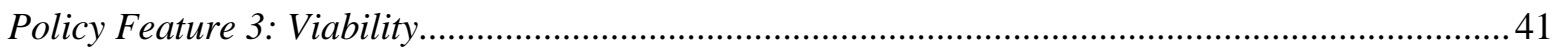

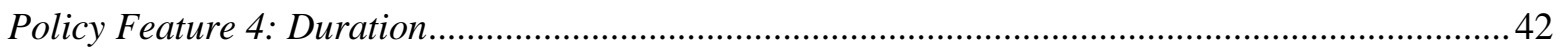

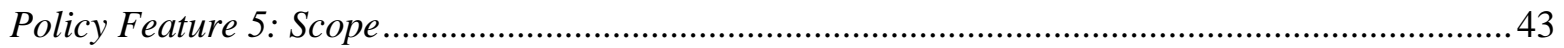

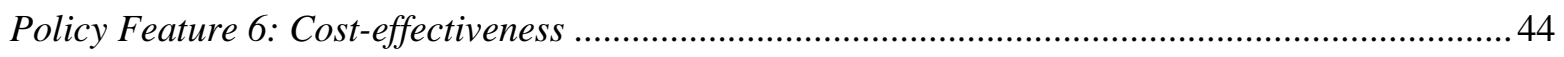

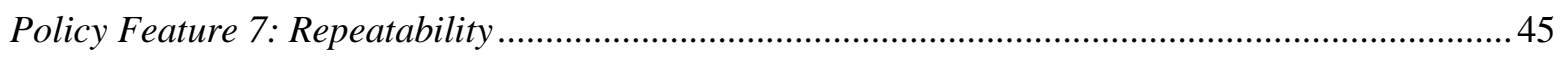

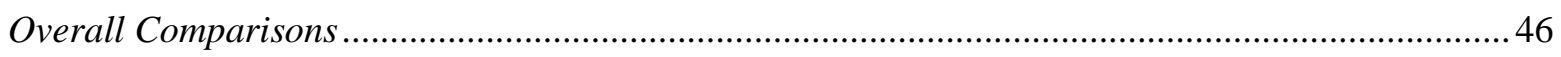

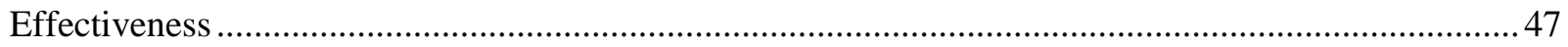

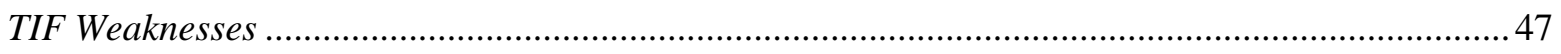

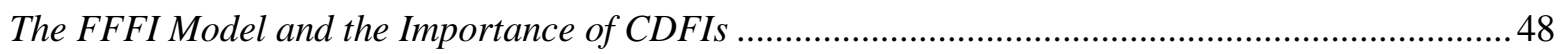

Conclusions Drawn from Policy Analysis ..................................................................................................... 49

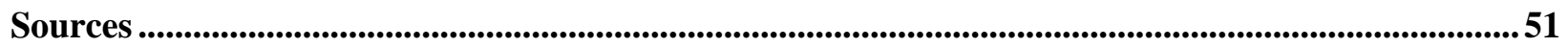




\section{Bringing Supermarkets into Food Deserts: An Analysis of Retail Intervention Policies}

Conversations addressing the problems associated with food deserts often turn at some point to the need for policies to redress limited food access. Food security issues and food inequality continue to present challenges for policy makers. Programs such as WIC (Women, Infants and Children nutrition) and SNAP (Supplemental Nutrition Assistance Program, formerly the Food Stamp program) are designed to serve at-risk and underserved populations by increasing access to nutritious food. Yet, what value does an EBT (electronic benefit transfer) card have when a SNAP recipient has few if any food retail options within a one mile radius? Proximity matters for those who may have limited transportation options. It may be easier and more convenient to purchase highly processed foods that can be linked to obesity and other health risks. Health and nutrition are important and often serve as the point origin for many current food initiatives and policies. Because it is the precursor to health and wellness and the focal point of policy efforts, this paper proposes to focus on food access.

Part One will provide a background regarding food deserts, retail as it relates to food systems, retail intervention policies, and a rationale for policy interventions. Part Two presents details regarding the methods of inquiry used in this analysis. Part Three gives an overview of recent food policies at the national level. Case studies comprise Part Four, wherein the paper will compare retail intervention efforts in Liberty City, Pennsylvania, Chicago, New Orleans, and Kansas City. In Part Five, the discussion will evaluate the merits of these case study policies and determine impact and replicability.

\section{Part One: Background}

This section provides a context for terminology and concepts used in this paper. The discussion introduces the term food deserts, offers several definitions, and includes ongoing challenges for scholars and policy makers in applying the term. The section also introduces the concept of food systems and establishes a framework for retail as a key component within food systems. Because barriers to food access frequently occur within the retail component, this section concludes with a rationale for retail intervention policies. The justification for policy interventions is rooted in historical and social equity based arguments.

\section{Food Deserts}

The earliest scholarly attempts to discuss food deserts began with Cummins and Macintyre (2002), who cautioned against policy making based on unquestioned acceptance of factoids unsupported by data-driven evidence. According to the authors: 
[T]he term 'food desert' was reputedly first used by a resident of a public sector housing scheme in the west of Scotland in the early 1990s. It first appeared in a government publication in a 1995 document from a policy working group of the Low Income Project Team of the then Conservative government's Nutrition Task Force. (p. 436)

The term stuck, and policy makers, academics, and community groups began using food deserts to describe "poor urban areas where residents cannot buy affordable, healthy food” (Cummins \& Macintyre, 2002, p. 436).

Subsequent discussion of food deserts expanded from a predominant focus on heath concerns to also include issues of barriers and access. Defined by the 2008 U.S. Farm Bill as "an area in the United States with limited access to affordable and nutritious food, particularly such an area composed of predominately lower-income neighborhoods and communities” (United States Department of Agriculture [USDA], 2009, p. 1), food deserts have also been evaluated for prevalence and accessibility by the U.S. Department of Agriculture (USDA). In a 2009 report to Congress, USDA findings demonstrated that “23.5 million people live in low-income areas...more than 1 mile from a supermarket or large grocery store” (p. 35).

Although the existence of food deserts is well documented, there is little consensus among researchers as to how food deserts are created, how they should be characterized, who is affected by them, or what should be done about them. Bitler and Hader (2011) have noted that a proper economic analysis is required to understand how the components of price, demand, supply, and market failure have shaped the conditions commonly labeled as food deserts. Raja, Ma, and Yadav (2008) have argued that food deserts express racial disparities, where people of color have to travel farther for and pay more for lower quality food than do suburban whites. Rose, Bodor, and Swalm (2009) have suggested that in many cases, food deserts areas are actually "food swamps" where snack foods are more prevalent than healthy foods.

Lee and Lim (2009) maintained that proper GIS mapping efforts are required to determine where to concentrate efforts to alleviate food desert conditions, and the literature indicates that regional differences in access do exist. Leete and colleagues (2011) argued that what have commonly been described as food deserts tend to occur in concentrated urban areas on the East Coast, whereas West Coast spatial orientations result in less concentrated urban zones and what can be better understood as suburban enclaves and food "hinterlands" rather than deserts. In their analysis the authors noted that the issues may be as much about transportation barriers as an absence of grocery stores.

The USDA, PolicyLink, and many other organizations have documented the connection between limited food access and health risks. There is no proven causal relationship but research suggests a strong correlation that links diet-related diseases to limited supermarket access. Giang and colleagues (2008) 
found that in Philadelphia neighborhoods with limited supermarket access, a correlation exists between poor diet and higher incidents of obesity, diabetes, cancer, and heart disease among residents.

Although the term food desert lacks a standard definition, food access concerns related to health and nutrition are nonetheless shaping current public policies. Those fortunate enough to not have to struggle to obtain good nutritious foods may give little or no thought to all the complex processes involved that allow for such ease of access. But whether they are labeled as deserts, swamps, or hinterlands, many U.S. cities have regions plagued with food inequality. This paper will examine several of the recent policy interventions applied toward alleviating barriers to food access. In general, most of these policies focus on food retail, namely supermarkets and grocery stores.

\section{Food Systems and the Retail Component}

A food system, depending on how it is defined, has many components such as production, transportation, processing, distribution, preparation, and waste management (Hamm \& Baron, 1999). In a 2011 report titled A Food Systems Overview, Richman has illustrated a more complex food system by grouping components with an outer circle and an inner circle. The outer circle includes natural resources, technology/infrastructure, and society/culture. Components of the inner circle are food production, processing, distribution, retail/healthy access, and waste management. Any one of these components brings with it layers of complexity and associated issues that can affect access to food.

Urban food systems pose many challenges, but for urban and inner-city residents who live with food insecurity and inequality, the retail sector is where the most immediate breakdown to access occurs. In their 2010 review of the research into healthy food access, Truehaft and Karpyn maintained that supermarkets are where most people go for food. Giang and colleagues (2008) asserted that "[s]upermarkets have been found to offer a large variety of healthy foods with typically the lowest prices in comparison with other, smaller food stores” (p. 273). Not only do supermarkets serve as a proxy for healthy food access, they also create jobs, house ancillary services such as pharmacies and banks, and can help anchor economic development activities for a community (Bell \& Standish, 2009). This is not to suggest that supermarkets are the only source for food, but they tend to offer more healthy food options at lower prices. Where there is an absence of supermarkets, smaller grocery stores, such as corner markets, may exist to serve food retail needs, and may be a better fit for some environments but not all. Simply put, where there is no food retail, there is no food access, and fewer supermarkets means less access to food, healthy or otherwise. 


\section{Retail Intervention Polices}

Food deserts represent a dearth of available healthy food options within inner city regions. A policy perspective of the problem asks how communities can go about bringing more food retail opportunities to these regions. One response is an approach that can be described in the broadest terms as Retail Intervention Policies. Lee and Lim (2009) refer to retail intervention policies in arguing for the use of a complex spatial mapping system to identify priority funding areas. Beyond their use of the term, the specific phrase retail intervention policies does not appear elsewhere in literature which considers food access issues, food deserts, and supermarkets. Yet, the term provides a useful way to think about the issues discussed in this paper. Retail intervention policies have been implemented in different ways by various cities with varying degrees of success. In a survey of 32 cities that have successfully attracted supermarkets into food deserts, Pothukuchi (2005) found that there is no consistent, repeatable pattern. Cities have varied with regards to both the policies used and the type of agent (e.g., private developer, city planner, or community based organization) involved in sponsorship or financing. A primary goal of this analysis is to determine those policy strategies that have been most effective.

One aspect of the retail intervention policy approach that deserves consideration is the type of retail that is introduced. More attention is given to supermarkets, but some researchers maintain that efforts would be better spent trying to attract smaller grocery stores and strengthen networks between existing neighborhood stores (Raja, Ma, \& Yadav, 2008). There are also arguments for other alternative retail interventions such as food coops, CSAs (community supported agriculture organizations), farmers' markets, and urban farms. Although these alternative food resources have a role to play in alleviating food desert conditions, this paper will limit its focus to the policy dimensions surrounding food retail. The analysis will consider retail intervention policy efforts focused on supermarkets and to a lesser extent those efforts focused on smaller grocery stores. Figure 1 provides a graphical representation of the general concepts surrounding retail intervention policies. 


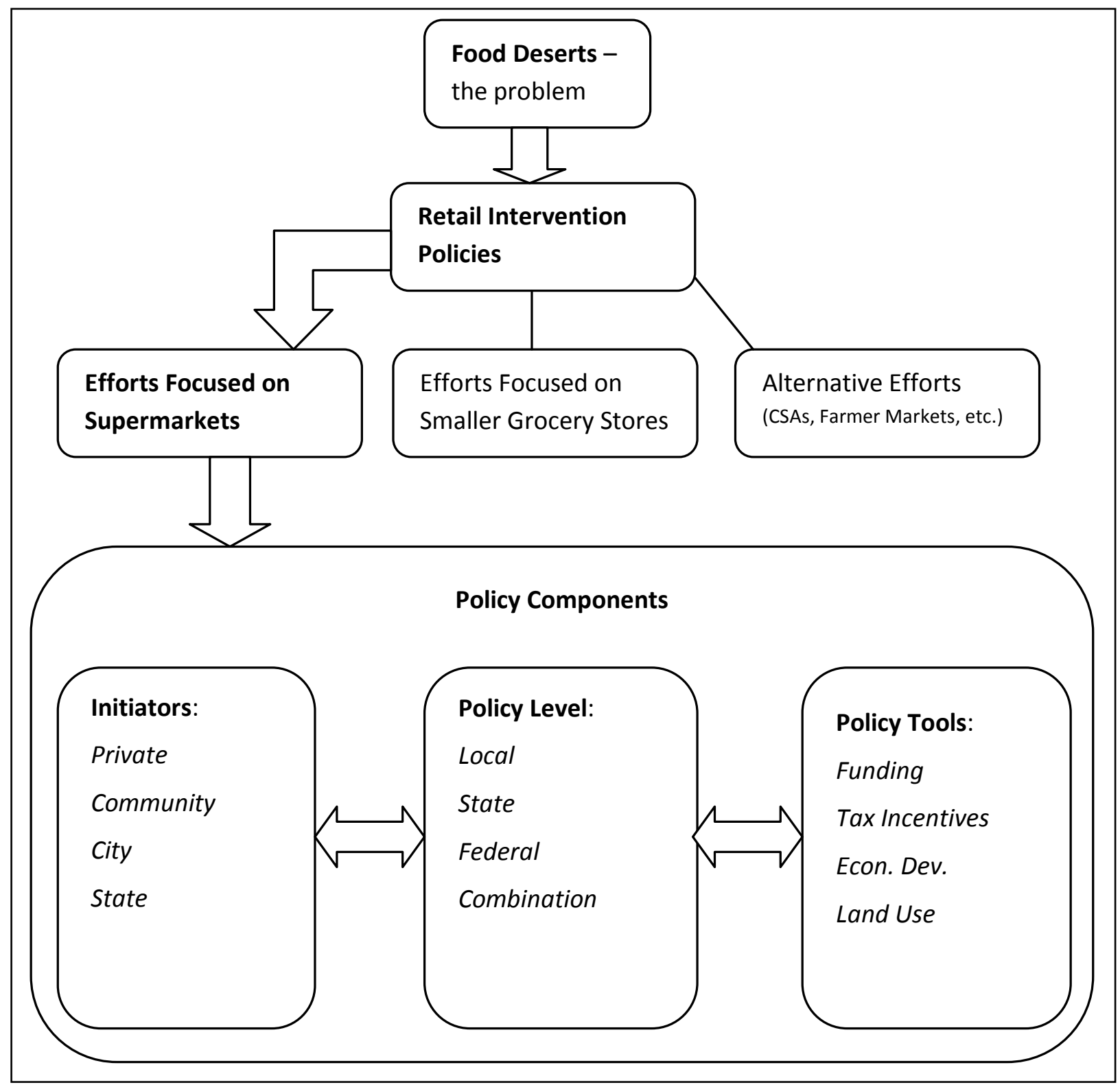

As depicted in Figure 1, retail intervention policy efforts tend to focus on one of three areas: Supermarkets, Smaller Grocery Stores, or Alternatives, which comprises CSAs, food coops, farmers' markets, community garden vendors, and urban farms. In general, efforts to bring food retail into food deserts entail three strategy components: Initiators, Policy Level, and Policy Tools. Initiators are the agents who initiate the food project, such as private developers, community organizations, city planners, or state agencies. Policy Level refers to the origin of the specific policy that an agent uses. The policy may come from the local, state, or federal level, or a combination of these levels. Policy Tools describes the allowable policy instruments used by agents to enact a food project. A Policy Tool may take the form of loans, grants, tax incentives, economic development, or land use/planning/zoning laws. Every Policy 
Tool has unique and complex characteristics, and it is likely that different intervention strategies will have different combinations of strategy components (Initiators, Policy Level, and Policy Tools).

Within this paper, the term food retail is used to refer to supermarkets, grocery stores, farmers' markets, food coops, community gardens, or essentially any retail operation that offers whole foods, basic ingredients, staples, and an assortment of food related products at reasonable prices. Food retail within this context does not include restaurants such as fine-dining, franchises, fast-food chains, or any establishment that focuses primarily on serving prepared meals.

\section{Rationale for Policy Intervention}

Because most policies represent a form of intervention that typically involve public services and funds, discussions need to address justifications of policies. This paper argues that government agencies (local, state, or federal) need to play some role in initiating, facilitating, or managing retail intervention policies designed to bring supermarkets to grocery stores. An assumption that guides day-to-day affairs in the private and public sectors in the contemporary political economy is the "acceptance of the market as the principal arbiter in the allocation of goods, services, wealth, and income in society” (DeFilippis \& Saegert, 2008, p. 67). Yet these allocations have not been equitable, nor has the market acted alone in creating inequities.

Public policy and the market created the trends that have led to population drains of urban city cores, the rise of the suburbs, and the resulting closure of inner city supermarkets. As O'Connor has noted, Roosevelt's New Deal sought to “promote home ownership among working- and middle-class Americans... at the expense of poor and minority city dwellers” (as cited in DeFilippis \& Saegert, 2008, p. 15). This public-private partnering created patterns of white flight to the suburbs that during the 1960s and 1970s, and supermarkets were among the business casualties of the population declines of the inner cities (Giang et al., 2008; Pothukuchi, 2005). For the low-income urban residents who were left behind, this meant traveling farther and paying more for lower quality foods.

The shameful inequalities of food access are predicated on bad policies and an amoral market system that does not arbitrate fairly in the allocation of goods and services. From a global perspective, these conditions of food access suggest greater moral implications of food security. Conditions of food security, as defined by the United Nations Food and Agriculture Organization, require at minimum that food be available, accessible, and nutritionally adequate (Koc \& MacRae, 1999).

Current patterns of racial inequalities, urban decline, food deserts, and limited food access have developed over a half century. To undo these conditions will take time and concerted efforts on the part of public agencies, private investors, community organizations, and the citizens themselves. As a matter of social equity and public administration, there is a moral imperative to determine how policy can do more 
to increase access to food, which ought to be a basic human right. Until it becomes so, policy makers and public administrators must figure out how to work within the necessary market and financial systems to bring food retail to underserved urban and rural areas.

\section{Part Two: Methodology}

To better understand retail intervention policies and their efficacy in bringing supermarkets into underserved areas, this policy analysis will follow a structured inquiry. Part Three will provide a brief overview at the national level regarding recent food initiatives and policies. This context will be helpful in creating a context for further policy comparisons. To prepare for making meaningful comparisons, the paper will draw from examples where policies have been used to bring in supermarkets or grocery stores. In Part Four these examples will take the form of the case studies from the following regions: Liberty City, Pennsylvania, Chicago and Illinois, New Orleans, and Kansas City. Within each case, the paper will identify policies that were used and try to explain how they work. Specifically, this analysis will assess policies for the following features:

- Strategy Components (Initiators, Policy Level, and Policy Tools)

- $\quad$ Funding Stream

- Viability (how easy/complicated is it to implement?)

- Duration (how long does it take to enact?)

- $\quad$ Scope (what kind of impact, how many stores?)

- Cost-effectiveness

- Repeatability (can it be replicated elsewhere?)

Information of the cases comes from a variety of sources, including program websites, reports, press releases, periodicals, and phone conversations. The extent of information available varies from case to case. The case studies present challenging exercises in research, knowledge building, and synthesis of meaning. Chronologies can be difficult to establish, and details such as costs are not always transparent or made easily accessible. In their original form, many source facts are not clear or transparent. The circumstances surrounding policy creation can be unsystematic and disorganized. Yet, this paper attempts to make sense of the sources and piece together enough details to present a coherent narrative. The case studies offer a look at the local conditions that drove the need for intervention as well as barriers that were encountered during the policy creation process.

Where appropriate some analysis will be offered within each case, helping to establish a basis for a comparisons and the meta-policy analysis in Part Five. The Part Five analysis will consider the policy 
models used for retail intervention and assess the effectiveness of these policies. Also important is repeatability; in other words, how well a particular policy intervention works when applied to another city or region of the country.

\section{Part Three: Recent Food Initiatives and Policies Overview}

In 2009, issues of food security began to enter the national consciousness with the publication of the U.S. Department of Agriculture's report to Congress on the problem of food deserts. In addition to identifying and describing the problem of food deserts, the study revealed that " 23.5 million people live in low-income areas that are more than one mile from a supermarket” (USDA, 2009, section 6).

In February 2010, the Obama Administration announced a Healthy Food Financing Initiative (HFFI) (U.S. Department of Health and Human Services [HHS], 2010) that would make over \$400 million available to organizations with feasible strategies to deal with food access in underserved communities:

The initiative will make available a mix of federal tax credits, below-market rate loans, loan guarantees, and grants to attract private sector capital that will more than double the total investment. Federal funds will support projects ranging from the construction or expansion of a grocery store to smaller-scale interventions such as placing refrigerated units stocked with fresh produce in convenience stores. (para. 8)

Initial HFFI funding was to be made available jointly through the Treasury Department, Department of Agriculture, and the Department of Health and Human Services. The Departments of the Treasury and Health and Human Services were each expected to offer funding and technical assistance for the purpose of bringing grocery stores to low income and underserved areas. Also during 2010, the USDA announced the availability of two online resources: the Food Environment Atlas (n.d.) and the Food Desert Locator (n.d.).

Congress did not appropriate any funds for HFFI in the 2011 budget but agencies were able to use existing authority and resources to provide \$45 million for HFFI projects in 2011 (PolicyLink, 2012). The 2012 budget allotted \$32 million to HFFI through the Departments of the Treasury and Health and Human Services. Of these funds, \$22 million is administered through the Treasury for CDFIs (community development financial institutions) and \$10 million is available "through the Community Economic Development Program at Health and Human Services for CDCs” that are working on health food programs (PolicyLink, 2012).

President Obama’s Budget for Fiscal Year 2013, which will go before Congress for review, proposes to continue with the commitment to combating food inequality by making available 
approximately \$400 million in financing to community development financial institutions, other nonprofits, public agencies, and businesses with "sound strategies for addressing the healthy food needs of underserved communities” (Office of Management and Budget, 2012, para 23).

There is no shortage of information available regarding strategies for attracting supermarkets and grocery stores to underserved urban areas. While this paper reviews many of these approaches, its objective is not only to catalog methods but to identify which stratagems have succeeded and why. To that end, an examination of several case studies will help determine which policies and tools appear to be most effective in bringing food retail options to food deserts.

\section{Part Four: Case Studies, Past and Present Policy Efforts}

Part Four introduces several case studies to explore retail intervention policies in action. Each case presents the conditions driving the policy's creation, analyzes the features of the policy, and assesses the likelihood that the policy could be repeated elsewhere. The Liberty City case provides one of the first documented efforts to bring a supermarket into a distressed urban area. Pennsylvania’s Fresh Food Financing Initiative (FFFI) sets the gold standard for effective policy creation and implementation. Illinois State and the City of Chicago cases provide examples of complex and concurrent yet unconnected policies. Rated as the city with worst food desert conditions, New Orleans and the Fresh Food Retailer Initiative illustrate a similar approach to Pennsylvania's FFFI, but with several variations. Finally, while Kansas City offers instances of policy forms other than retail intervention that have been used to bring in supermarkets, its disparate efforts do not reflect any cohesive plan for food access.

\section{Liberty City, Dade County, Florida}

Partly situated in northwestern Miami and partly in unincorporated Dade County, Florida, the nine-square-mile area of Liberty City gained notoriety in 1980 when riots broke out in reaction to a court case bearing eerie similarities to the Rodney King trial that would ignite the Los Angeles riots in 1992. Four white policemen were charged with beating a black insurance agent to death. When a Tampa jury found the officers not guilty, violence erupted, resulting in 18 fatalities, 1100 arrests, and approximately \$100 million in property damages (4VF News, 2008). Amid the destruction, community leader Otis Pitts saw an opportunity for a community to heal and rebuild. His efforts ultimately led to the building of a new Winn Dixie supermarket, which then served as an anchor for an entire shopping center of businesses and services that would benefit the community.

In a St. Petersburg Times opinion piece, Paul Grogan, president of Local Initiatives Support Corp., asserted that initial efforts to rebuild Liberty City followed a top-down approach in which civic leadership raised \$7 million in venture capital funds to be designated for “black capitalism” in hopes of 
stimulating minority entrepreneurship (Grogan, 1992, p. 15A). This "spasm of guilt among city fathers" amounted to "unsound proposals made by black Miamians whose political ties to decision-makers at the center were stronger than their ties to the neighborhood” (Grogan, 1992, p.15A). Beyond the fruitless efforts of the Miami business community, federally driven responses did not fare much better. An investigation by the Government Accountability Office revealed that only $\$ 70.6$ million of the $\$ 116$ million in available Federal aid had reached Dade Country, and much of it went outside the riot-stricken area ("U.S. aid to Miami," 1985). And of the \$16 million in loans provided by the Small Business Administration, only 4\% went to black-owned businesses ("U.S. aid to Miami," 1985). In short, the millions of federal dollars poured into rebuilding Liberty City evaporated or were siphoned off to places other than the community itself.

Success at rebuilding the community needed to originate from within the community. What could be called a grow-your-own approach to rebuilding occurred when LISC (Local Initiatives Support Corp.) and Otis Pitts joined forces. LISC, created by funding from the Ford Foundation, came to the Miami shortly after the riots, seeking ways that the communities might rebuild. LISC did not find any active CDCs (community development corporations) in the area but recognized Pitts as a community leader with potential and provided him with the opportunity to visit other cities where LISC-supported CDCs had been formed (Allen, 1994). A former police officer, Pitts served as director at a local community center and knew the Liberty City community very well. More important, he believed that rebuilding the community was possible. Pitts told the Chicago Tribune, "The reason I believed was that I had seen it in other places" (Allen, 1994, para 12). He felt that a successful investment that also met a need "would be catalytic. It would also be symbolic, being at the entrance to the community" (Allen, 1994, para 19).

In 1982, Pitts founded the Tacolcy Economic Development Corporation (TEDC).With the help of LISC, TEDC obtained the following funds for the successful development, building, and initial operating costs of the Edison Plaza Shopping Center (Pierce, 1985):

- $\quad$ LISC, $\$ 250,000$

- The City of Miami, $\$ 650,000$

- Dade County, $\$ 260,000$

- Economic Development Administration (federal), $\$ 800,000$

- City Business Leaders, $\$ 250,000$

- Winn Dixie, $\$ 2,000,000$

Where many supermarkets would have balked at entering the site of a burned out supermarket, Winn Dixie saw potential in Liberty City. There was no competition. The benefits gained by nabbing up the entire market share would more than offset the inherent higher costs of opening and operating a grocery store in an urban environment. Winn Dixie opened in March of 1985. All told, the 48,000 square-foot 
shopping center cost \$2.1 million to build, included an African-American-owned pharmacy, generated 135 jobs, and served 12,000 to 17,000 customers a week (Allen, 1994).

The development of Liberty City's Edison Plaza Shopping Center provides one of the first examples of policy based efforts to bring a supermarket into an underserved area. Liberty City failures and successes at rebuilding offer lessons for other communities looking to attract a supermarket. What does not work are "federally run, top-down, paternalistic attempts by politicians and the Chamber of Commerce to tell the inner city how to rebuild” (Booth, 1999, p. A3). From LISC director Paul Grogan’s perspective, progress only happened when “[v]isions of overnight transformation were replaced by a program that stressed creation of the community's own capacity to direct renewal and take responsibility for the results. Outside capital and expertise were brought in to serve that vision, not to generate it” (Grogan, 1992, p. 15A). Grogan argued for “properly nurtured self-help” whereby a community sets its own course. TEDC had a focused goal and was able to secure dollars from the city, county, federal, and private sector. This momentum drew in the largest contributor of all, Winn Dixie itself.

Table 1 provides a summary of policy assessment features evident in the case of Liberty City. 
Table 1

Edison Plaza Shopping Center / Winn Dixie

\begin{tabular}{|c|c|}
\hline $\begin{array}{l}\text { Strategy } \\
\text { Components }\end{array}$ & $\begin{array}{l}\text { Initiators: Otis Pitts, LISC, TEDC. } \\
\text { Policy Level: Community } \\
\text { Policy Tools: Public Investments to Leverage Private Partnership \& Investment } \\
\text { Tax Credits. }\end{array}$ \\
\hline Funding Stream & $\begin{array}{l}\text { Multi-sourced: } \\
\text { LISC \$250K; City \$650K; Dade County \$260K; Econ. Dev. Admin. (Federal) } \\
\$ 800,000 ; \text { City Business Leaders } \$ 250 K ; \text { Winn Dixie } \$ 2 \text { million. }\end{array}$ \\
\hline Viability & $\begin{array}{l}\text { Details of exactly how investors were persuaded and secured are not clear. } \\
\text { Given that initial efforts of City businesses and Federal funds failed to produce } \\
\text { results, the challenge to Pitts and TEDC was likely enormous and difficult to } \\
\text { implement the processes. }\end{array}$ \\
\hline Duration & $\begin{array}{l}\text { From the time TEDC was founded in 1982, it took } 3 \text { years get Winn Dixie in and } \\
\text { open by } 1985 . \\
\text { It would be } 5 \text { years when included the failed efforts starting in 1980.Counting } \\
\text { from Food Trust's initial efforts in 2001, it took } 9 \text { years. }\end{array}$ \\
\hline Scope & $\begin{array}{l}\text { Edison Plaza Shopping Center, } 48,000 \text { sqft. cost } \$ 2.1 \text { million to build. } \\
\text { Created } 135 \text { jobs \& served } 12,000 \text { to } 17,000 \text { customers per week. }\end{array}$ \\
\hline Cost-effectiveness & $\begin{array}{l}\text { When compared to the wasted business investments of } \$ 7 \text { million and the tens } \\
\text { of millions of federal dollars wasted, } \$ 2.1 \text { million spent to create a successful } \\
\text { shopping center with a grocery store seems like a bargain. }\end{array}$ \\
\hline Repeatability & $\begin{array}{l}\text { This may be a difficult case to replicate. A community would need a strong } \\
\text { willed, visionary leader. It would need a CDC that was interested in } \\
\text { supermarkets. The leader and the CDC would need to be able to secure } \\
\text { partnered investments from public and private sources. }\end{array}$ \\
\hline
\end{tabular}

In assessing retail intervention policies, the Liberty City case serves as a reminder that top-down control does not work. But local and federal government can assist by making capital available. What is difficult to determine is exactly how Otis Pitts was able to create support and form collaborations.

Because we know less about what tools and methods he might have used, the Liberty City model is very much tied to one individual. If Otis Pitts were not instigating the community rebuilding process, would the Edison Plaza Shopping Center and Winn Dixie have been built? Also, there is the LISC variable. The limitations of this case study do not tell us much more than the fact that LISC identified and supported Pitts. LISC provided funding and most likely guidance as Pitts formed TEDC. But does this mean that if LISC had not entered the picture, Pitts would have been unsuccessful in creating TEDC and initiating the 
shopping center project? While Liberty City presents a dramatic narrative, too many questions remain unanswered for this to serve as a replicable model for attracting supermarkets.

\section{Pennsylvania's Fresh Food Financing Initiative}

As more cities begin to address issues concerning access to healthy, nutritious food as well as efforts to combat food deserts, Pennsylvania has been ahead of the curve and has set the bar with regards to developing financing programs to attract supermarkets into underserved areas. The Obama Administration's 2010 Healthy Food Financing Initiative is in fact modeled on the Pennsylvania Fresh Food Financing Initiative (FFFI) program (HHS, 2010).

The origins of the FFFI program can be traced to its primary initiator, The Food Trust, a Philadelphia-based nonprofit that works to improve access to healthy food. The Food Trust formed in 1992, during a time in which Philadelphia was ranked among the top four most obese cities and had "the second-lowest number of supermarkets per capita in the United States” (Chirouze, Atlas, \& Rajaruru, 2010, p. 2). The Food Trust wanted to counter these trends and began examining the link between obesity, health, and food access by conducting evidence based studies that drew from asset mapping, Census data, studies of diet related health risks, and supermarket locations within Philadelphia. Its findings were published in reports such as The Need for More Supermarkets (Perry, 2001), which used extensive mapping to illustrate such factors as supermarket sales, population, income, diet-related deaths, and areas with the greatest supermarkets needs.

These reports gained the attention of the city council and brought about the partnering of government and industry, resulting in the formation of a Food Marketing Task Force. The task force was composed of civic planners, economic development agencies, and supermarket industry experts, and cochaired by the CEO of the United Way of Southern Pennsylvania and the vice president of Acme Markets. The task force looked at the opportunities and barriers involved in bringing supermarkets into Philadelphia's underserved areas and cited financing as the "single greatest obstacle to stimulating grocery retailing in underserved communities” (Bell \& Standish, 2009, p. 84). According to supermarket operators, the higher costs associated with urban locations made it unlikely that conventional loan institutions could provide appropriate financing. In response to these findings, the task force recommended that a statewide fund be created to support fresh food retail development (Bell \& Standish, 2009).

Inspired by the task force findings and recommendations, state representatives Frank Oliver, Dwight Evans (both from Philadelphia), and Jake Wheatley (from Pittsburgh) called for the Pennsylvania House Committee on Health and Human Services to hold hearings on the grocery gap. Based on these hearings, the state made an initial allocation of \$10 million for the formation of the Fresh Food Financing 
Initiative (FFFI) in 2004. The state made additional allocations in 2005 and 2006, each in the amount of \$10 million (Giang et al, 2008). The state then contracted with The Reinvestment Fund (TRF), a community development financial institution (CDFI), to manage the \$30 million state seed money. According to Bell and Standish, “over the next five years, TRF attracted \$165 million in private investment to create a multifaceted, flexible loan and grant program” (2009, p. 85).

The Fresh Food Financing Initiative provides funding to qualified supermarkets and retailers through direct grants, a Core Loan Fund, and federal New Market Tax Credits (NMTC) (Evans, 2010). Currently, TRF manages the FFFI program, assists The Food Trust with the grant application process, and handles all post award reporting requirements tied to federal funds, such as New Market Tax Credits (NMTC). FFFI helps cover various start-up costs through grants and loans, providing grants of up to \$250,000, and loans that range from \$25,000 to \$7.5 million (New Rules Project, n.d.). Bell and Standish have noted that these funds can be used toward any stage of a project including "pre-development, land acquisition, equipment financing, capital grants for project funding gaps and construction, and permanent finance” (2009, p. 85). Supermarkets and grocery stores can qualify for FFFI funds based on existing store locations and customer base. The Reinvestment Fund defines a store's trade area as approximately .5 mile within inner city areas, and stores that are not in low income census tracts may qualify for FFFI funding if more than $50 \%$ of the customer base is from a low income census tract (The Reinvestment Fund, 2010). By offering funding support to remove financial barriers, FFFI serves its mission to increase food access by working to bring supermarkets and grocery stores into underserved communities. TRF reports that as of June 2010, FFFI has had 206 funding applications and has approved 93 for funding.

Whether evaluating outcomes or impacts, FFFI has demonstrated success in Pennsylvania. According to The Food Trust, FFFI funding achievements include 88 food-retail projects spanning 34 Pennsylvania counties, the creation or preservation of more than 5,000 jobs and improved "access to healthy food for more than half a million people” (The Food Trust, 2004, para. 5). Economics analysis consulting firm Econsult conducted an impact study of FFFI. Communities with supermarket developments showed improved real estate values, increased economic activity, and greater access to better quality food at lower prices (The Reinvestment Fund, 2010).

Finally, Chirouze and colleagues (2010) considered an SROI (social return on investment) formula based on the addition of three categories: reduction in chronic disease expenditures, increase in productivity, and jobs created times the average annual salary. Each of the three categories can be broken down further into formulas using data from chronicdiseaseimpact.org for the first two items and data from The Food Trust and the U.S. Department of Labor for the job creation category. Based on the calculations, FFFI’s SROI totals $\$ 2.23$ billion. 
How did FFFI achieve these successes? There are many considerations. First, though the scope of the initiative appears large and the benefits extend beyond the entry of supermarkets themselves, "the singular focus of the campaign centered around the stimulation of supermarket development in lowerincome neighborhoods” (Giang et al., 2008, p. 278). The history of policy making provides many examples of large sweeping policies aimed at economic development and social change that amounted to millions of dollars spent with seemingly minimal results. In contrast, FFFI does not try to do more than bring supermarkets to underserved areas. This targeted approach yields better results because its scope is more modest and focused.

FFFI's policy characteristics also include an interesting chronology. At the start, The Food Trust was instrumental in defining the vision, leading the way, and providing strong community-based advocacy. The Food Trust built support through the development of evidence-based reports. Without reports such as The Need for More Supermarkets in Philadelphia (Perry, 2001) and Stimulating Supermarket Development: A New Day for Philadelphia (Burton \& Perry, 2004), it is likely that civic leaders would have never championed the FFFI cause. The Food Trust was also savvy in its efforts to attract industry leaders. With the special report entitled Philadelphia's New Markets: Ripe Opportunities for Retailers, Johnson-Piett and Food Trust colleagues (n.d.) reframed the discussion from one of supermarket need to one of retail opportunities. The authors argued that Philadelphia had a large untapped consumer density with retail buying power equal to at least $\$ 50$ million per square mile. Yet, due to the dearth of supermarkets and unmet demand, retail float (or leakage) meant that these millions of dollars were being spent outside the communities. Whether calling for need or presenting opportunities, The Food Trust set the FFFI in motion.

The middle stage of FFFI policy development dealt with the state's involvement. State representatives, the Food Marketing Task Force, and the Pennsylvania House Committee on Health and Human Services were essential to FFFI. What began as a city based initiative concerned with urban communities proved to have important ramifications for the entire state, where many communities struggled with health problems, obesity, and limited access to healthy foods. The state buy-in culminated in the initial investment of \$30 million to establish FFFI. Also, the state's efforts included the contracting of a capable CDFI (community development financial institution), The Reinvestment Fund (TRF).

The final phase of FFFI policy development entailed the delivery of policy objectives, or the provision of financial assistance necessary for supermarkets to enter urban areas. TRF has made this delivery possible by providing technical assistance and administering the financing for the Direct Loans, the Core Loan Fund, and the New Markets Tax Credits (NMTC). As FFFI is ongoing, TRF continues to play a major role and has emerged as the premier financial expert in attracting supermarket and grocery into communities. TRF also has made much of its technical expertise available in dynamic ways, such as 
its PolicyMap mapping tool designed to allow communities (and anyone with Internet access) to identify areas with Limited Supermarket Access (LSAs) (The Reinvestment Fund, 2012).

Only a CDFI would have the financial know-how to achieve the complex loan packages and leveraging necessary to secure investments. As an example, TRF's Core Loan Fund is built on a partnership with a pool of banks that allowed the creation of bank-syndicated loan funds. There are eight bank/financial institutions within this pool, all contributing a portion of $\$ 40.5$ million available for loans (The Reinvestment Fund, 2010). This way, no single institution bears 100\% of the risk involved in financing supermarket startup costs. Without TRF, or a CDFI that offers both skill in financing and expertise in supermarket mapping, FFFI would not work.

Table 2 summarizes FFFI's overall policy features.

Table 2

Fresh Food Financing Initiative

\begin{tabular}{|c|c|}
\hline $\begin{array}{c}\text { Strategy } \\
\text { Components }\end{array}$ & $\begin{array}{l}\text { Initiators: The Food Trust, State Representatives. } \\
\text { Policy Level: Statewide. } \\
\text { Policy Tools: Financing via Direct Grants, Core Fund Loans, New Market } \\
\text { Tax Credits. }\end{array}$ \\
\hline Funding Stream & $\begin{array}{l}\$ 30 \text { million in state seed money. } \\
\$ 165 \text { million from TRF in leverage private investments. } \\
\text { TRF received } 3 \text { NMTC allocations totaling } \$ 278.5 \text { million. }\end{array}$ \\
\hline Viability & $\begin{array}{l}\text { State involvement likely due to advocacy, organization, efforts \& } \\
\text { partnerships of The Food Trust. } \\
\text { Financing is complex, but TRF, a CDFI, can manage the financing } \\
\text { processes. }\end{array}$ \\
\hline Duration & $\begin{array}{l}\text { Based on creation in } 2004 \text { \& approved funding for } 93 \text { applications in } \\
2010, \mathrm{FFFI} \text { took } \\
6 \text { years to implement. } \\
\text { Counting from Food Trust's initial efforts in 2001, it took } 9 \text { years. }\end{array}$ \\
\hline Scope & $\begin{array}{l}88 \text { fresh-food retail projects, spanning } 34 \text { counties. } \\
5000+\text { jobs created/preserved } \\
\text { Increased food access for more than a half-million people. }\end{array}$ \\
\hline Cost-effectiveness & $\begin{array}{l}\text { Considering the costs of } \$ 195 \text { million }(30+165) \text { initial investments, the } \\
\text { SROI of } \$ 2.23 \text { billion plus } 88 \text { stores plus } 5000+\text { jobs, the benefits clearly } \\
\text { outweigh the costs. }\end{array}$ \\
\hline Repeatability & $\begin{array}{l}\text { If a city has a non-profit group with strong community ties and } \\
\text { persuasive advocacy, some seed investment funds, and a capable CDFI, } \\
\text { then a similar FFFI would be feasible. }\end{array}$ \\
\hline
\end{tabular}


Pennsylvania’s FFFI program has led the way with food retail intervention policies. With its innovative policy, FFFI has proven effective at overcoming the financial barriers that prevent grocery stores and supermarkets from entering many urban areas, and based on its reported program outcomes, it would seem reasonable to conclude that as new grocery stores have opened throughout the state, food access has improved for thousands of Pennsylvanians. The FFFI program is lauded as the model that should be implemented at a national scale and many cities nationwide are looking to the program to see how it may be duplicated (Urban Portal, 2011). However, it is still too soon to know how easily replicable the FFFI model will be. The following discussion will review the policy efforts in Chicago and Illinois to determine how closely these mirror the components, strategies, and successes of FFFI.

\section{Illinois Fresh Food Fund and Chicago-Based Efforts}

Although both Chicago and Illinois are cited as locales where supermarket retail intervention policies are underway, city and state efforts are unconnected. Illinois did launch an FFFI inspired initiative called the Illinois Fresh Food Fund but the initiative appears to have had no apparent impact. Further complicating the Illinois Fresh Food Fund narrative is the fact that this statewide initiative was generated from a city-based set of concerns in Chicago. All the while, in Chicago, a different set of grocery store efforts have been underway that have no connection whatsoever to the Illinois Fresh Food Fund. To better understand these dynamics, it will help to examine a brief history of food retail policy efforts in both Chicago and Illinois.

In Chicago, efforts to address food access issues began in 2005. Mayor Richard Daley and the city council made the first attempts to remedy limited food access in underserved areas through programs promoting sustainability and food businesses. For Daley, healthy food access was tied to a larger vision of transforming the Windy City to a Green City that emphasized environmental friendliness, organic gardening, and farmers' markets (American Farmland Trust, n.d.). However, the transformation from vision and programs into overall food access policy never took place. According to one urban farmer, "Daley supported a lot of [food businesses], but his departments were structured like silos with a lack of integration and communication” (Eng, 2011, para. 7).

Supermarkets entered the conversation when in 2005 the Metro Chicago Information Center reported that wealthier Chicago neighborhoods had double the number of supermarkets as compared with lower income neighborhoods (The Food Trust, 2005). Philadelphia’s Food Trust also played a role in providing research and mapping that documented the link between limited supermarket access and dietrelated deaths. These findings led the Food Trust to join forces with the Illinois Food Retailers Association, the Illinois Retail Merchants Association, and Voices for Illinois Children to form the Illinois Food Marketing Task Force (The Food Trust, 2005). At this point in the Chicago/Illinois food 
policy chronicles, the city-state link was formed. But this connection would not result in a cohesive FFFIinspired policy that would unify and benefit both the City of Chicago and the state of Illinois.

\section{Illinois Fresh Food Fund}

As noted, research and mapping tools were developed by The Food Trust to help identify causal links between supermarket absence and ill health. In a 2008 special report titled The Need for More Supermarkets in Chicago, Perry, Harries, and Goldblatt argued that food access solutions require not only public investment but also the strategic collaboration of private, public, and community sectors and the creation of local and state government-funded grant and loan programs. Soon after the publication of this report, the Illinois Food Marketing Task Force was convened. Strategies followed as the task force spent a year researching three main issues related to increasing supermarket access: benefits to health and the local economy, barriers to project investments, and policies that could remove barriers (O’Connor, 2009). In May of 2009, the Illinois Food Marketing Task Force took its recommendations to the state capitol, calling for legislators to create an Illinois Fresh Food Fund initiative and approve \$10 million for its formation (O’Connor, 2009). Through loans and grants, the $\$ 10$ million in state seed money would be made available to qualified grocery stores to help defray the higher costs associated with opening stores in lower income neighborhoods (O’Connor, 2009). Also, the funds would be strategically leveraged to obtain an additional \$20 million in private investment and other sources. A few months later, Harries and colleagues (2009) published a report titled Stimulating Supermarket Development in Illinois: Healthier People, Healthier Communities \& a Healthier Economy detailing these recommendations to the state. In addition to advocating for the creation of the Illinois Fresh Food Fund, the allocation of \$10 million, and public-private partnerships, the report also called for reduced regulatory barriers to supermarket investments and priority to land acquisition for supermarket development (Harries, Holtzman, Lang, \& Perry, 2009). In July 2009, the Illinois Senate passed Bill 1221, in which Section 200 appropriated \$10 million for the Illinois Fresh Food Fund initiative (Bloyd, Braun, Williams, \& Kelly, 2011).

The creation of the Illinois Fresh Food Fund represents a milestone in the efforts of the Illinois Food Marketing Task Force and distinguishes Illinois as the third state to adopt a food financing initiative (Pennsylvania was first, followed by New York). But what progress has followed from the creation of the initiative? Bloyd and colleagues (2011) have identified several weaknesses in the operations of the Illinois Fresh Food Fund initiative, including:

- Lack of participation from affected communities

- Lack of opportunities for public involvement

- Lack of transparency in the initiative process 
- Overrepresentation of the supermarket industry

- Concerns that the $\$ 10$ million in funds is insufficient

- Stalling of progress when The Food Trust ended active involvement

These issues have presented obstacles to Illinois Fresh Food Fund efforts to translate the \$10 million into loans, grants, additional financial leveraging, and overall efforts to bring supermarkets into the communities that need them. Two observations are worth noting. First, there is no dedicated website for the Illinois Fresh Food Fund nor does it have a page allotted within a larger organizational website, such as the State of Illinois. This indicates a lack of ownership and leadership of the initiative. A commonly discussed topic in the connection between law and public administration is that laws do not administer themselves. Just because the state passed the bill allowing for the creation of the Illinois Fresh Food Fund does not guarantee that the initiative will be run effectively.

A second observation is that The Food Trust essentially authored the two key reports that prompted the creation of both the Illinois Food Marketing Task Force and the Illinois Fresh Food Fund initiative. This suggests that although the Philadelphia based Food Trust provided technical expertise and guidance, the hope was that an Illinois based organization would step up and take over. That this has not happened helps explain the lack of transparency and absence of community involvement in the initiative. The supermarket industry's involvement, on the other hand, can be seen as a natural consequence of the subsidies these companies stand to gain from the \$10 million, such as defrayed costs associated with opening new stores. Yet without the guidance of an advocacy group like The Food Trust, there is no agent looking out for the good of the communities. As of this writing, the Illinois Fresh Food Fund has no advocacy group linked to it in the way that The Food Trust operates with Pennsylvania's FFFI.

One oversight in the strategic planning of the Illinois Fresh Food Fund lies in the assumption that a CDFI would emerge or be identified to help manage the initiative. Although one report indicated that Illinois was preparing an RFP (request for proposal) to identify a partner organization to implement the program, there is no evidence that this has happened (Chirouze, Atlas, \& Rajaruru, 2010). Without a CDFI on board, there is little to no chance that the $\$ 10$ million will be leveraged to bring in additional financing. From this perspective, \$10 million is not insufficient funding. Rather, there has been insufficient financial leadership and know-how required to grow those funds as Pennsylvania's FFFI was able to do with its $\$ 10$ million in state seed funds. If there are efforts to leverage the funds and if a CDFI is in fact on board, these facts are not transparent. All evidence suggests that that although the Illinois Fresh Food Fund has set sail, no one is commanding the ship.

Table 3 summarizes key details of the Illinois Fresh Food Fund. 
Table 3

Illinois Fresh Food Fund

\begin{tabular}{|c|c|}
\hline $\begin{array}{c}\text { Strategy } \\
\text { Components }\end{array}$ & $\begin{array}{l}\text { Initiators: The Food Trust \& the Illinois Food Marketing Task Force } \\
\text { Policy Level: Statewide. } \\
\text { Policy Tools: Direct Loans \& Grants. Financial leveraging. }\end{array}$ \\
\hline Funding Stream & $\$ 10$ million in state seed money. \\
\hline Viability & $\begin{array}{l}\text { Without the advocacy, organization, efforts \& partnerships of the } \\
\text { Food Trust, the State may not have allocated funds. } \\
\text { The project current lacks advocacy-based leadership. No CDFI has } \\
\text { emerged to managing financing. }\end{array}$ \\
\hline Duration & $\begin{array}{l}\text { If count the first reporting efforts from } 2005 \text {, it took nearly } 4 \text { years for } \\
\text { the creation of the Illinois Fresh Food Fund. Counting from the Food } \\
\text { Trust's first report in } 2008 \text {, it took a little over } 1 \text { year. If we average } \\
\text { these, we could estimate } 2.5 \text { years. }\end{array}$ \\
\hline Scope & $\begin{array}{l}\text { There is not enough information to determine the scope of the } \\
\text { initiative. The idea was that it would grow and be a statewide } \\
\text { program. }\end{array}$ \\
\hline Cost-effectiveness & There is not enough information to determine this. \\
\hline Repeatability & $\begin{array}{l}\text { This initiative failed to enlist a local nonprofit/community-based } \\
\text { advocacy group to the lead, from initiation phase to identification of } \\
\text { communities in need. Also, a CDFI was not contracted to manage the } \\
\text { program or help grow funding. A state wanting to implement a similar } \\
\text { program would need to include both agents. }\end{array}$ \\
\hline
\end{tabular}

What has the Illinois Fresh Food Fund initiative achieved? Taking stock of the seven policy elements, the initiative has very little to show in terms of outcomes or impacts, although it may be too soon to judge the efficacy of the program. In terms of its replicability, it may be more instructive to identify what not to repeat when trying implement a similar policy initiative.

\section{Chicago Based Efforts}

Though not much appears to be happening with Illinois Fresh Food Fund, many supermarket related efforts have been underway in Chicago. It is worth pointing out that the efforts culminating in the Illinois Fresh Food Fund originated out of Chicago. Yet the Chicago based efforts to attract supermarkets and combat food deserts are not tied to the Illinois Fresh Food Fund. At best, policy efforts between the city of Chicago and the state of Illinois have been disconnected. Supermarket efforts occurring in Chicago 
generally reflect one of two trends, public-initiated or corporation-initiated, although not all efforts fall squarely into one of these two categories The public-initiated trend reflects the national discourse surrounding access to healthy foods. Those in public office can be the initiators and advocates in attempts to create food access policies that influence private entities in the launching of supermarket projects. The corporation-initiated trend grows out private supermarket company efforts to either influence or access public policy to initiate supermarket projects. The supermarket companies may be responding to national health food access discourse and may be motivated by access to funding that would defray new store building and operating costs. The corporation-initiated efforts have resulted in the most significant impact, and this will be discussed further in this section. These two trends are presented as a way to think about the directional flow of influence in shaping policy and initiating supermarket entry projects.

To complicate matters, various Chicago based efforts may have overlap with intentions and goals, but there is an overall silo effect in which initiators, resources, and tools operate separately without unison under a cohesive policy. Neither Chicago trend is directly linked to the Illinois Fresh Food Fund. In many instances, public efforts stem from meetings, reports, task forces, and publicity events. Corporate efforts include studies conducted by private consulting companies and corporation-initiated openings of stores such as Wal-Mart, Walgreens, and Supervalu. Figure 1 shows a timeline of key Chicago initiators and events.

Figure 1

Timeline of Chicago Public and Corporation Initiated Efforts

\begin{tabular}{|c|c|c|}
\hline Time & Event & Effort \\
\hline 2005 & A city task force met in response to wave of grocery store closings. & Public \\
\hline 2005 & $\begin{array}{l}\text { Metro Chicago Information Center reports that wealthier neighborhoods have } 2 x \text { as many } \\
\text { supermarkets as lower income neighborhoods. }\end{array}$ & Public \\
\hline 2006 & Gallagher Consulting publishes Examining the Impact of Food Deserts on Public Health in Chicago. & Corporation \\
\hline 2008 & The Food Trust publishes The Need for More Supermarkets in Chicago. & Public \\
\hline $\begin{array}{l}2010 \\
\text { June }\end{array}$ & $\begin{array}{l}\text { Gallagher Consulting publishes From Food Desert to Food Oasis: Blueprint for Change in Chicago, a } \\
\text { report commissioned by Wal-Mart. Argues that opening } 10 \text { new strategically located stores would } \\
\text { end food deserts. }\end{array}$ & Corporation \\
\hline $\begin{array}{c}2010 \\
\text { August }\end{array}$ & $\begin{array}{l}\text { Illinois Advisory Committee holds fact finding meeting to discuss Chicago Food Deserts \& begin } \\
\text { preparing reports showing racial disparities in food access. }\end{array}$ & Public \\
\hline 2011 & $\begin{array}{l}\text { Illinois Advisory Committee Reports on Chicago Food Deserts to the United States Commission on } \\
\text { Civil Rights. }\end{array}$ & Public \\
\hline $\begin{array}{c}2011 \\
\text { March }\end{array}$ & Gallagher Consulting recommends to Chicago City Council eliminate food deserts by 2014. & Corporation \\
\hline $\begin{array}{c}2011 \\
\text { October }\end{array}$ & $\begin{array}{l}\text { Gallagher Consulting publishes The Chicago } 2011 \text { Food Desert Drilldown arguing for ending food } \\
\text { deserts by } 2015 \text { not 2020. (not clear who commissioned report). }\end{array}$ & Corporation \\
\hline $\begin{array}{l}2011 \\
\text { June }\end{array}$ & $\begin{array}{l}\text { Mayor Emanuel "convened a private meeting of food store CEOs" and "promised to help fast-track } \\
\text { paperwork and create incentives to open new stores grocery stores in underserved communities" }\end{array}$ & Public \\
\hline
\end{tabular}




\begin{tabular}{|c|l|c|}
\hline Time & \multicolumn{1}{|c|}{ Event } & Effort \\
\hline $\begin{array}{c}\text { (Eng, 2011). } \\
\text { July }\end{array}$ & Wal-Mart opens first of 5 planned Wal-Mart Express stores. & Corporation \\
\hline $\begin{array}{c}2011 \\
\text { July }\end{array}$ & $\begin{array}{l}\text { Wal-Mart, Walgreens, and Supervalu stores all announce plans to open hundreds of stores over the } \\
\text { next several years. (Byfield-Green 2011). Michelle Obama also helps announce \& promote this plan, } \\
\text { linking it to her Let's Move campaign. }\end{array}$ & Corporation \\
\hline $\begin{array}{c}2011 \\
\text { October }\end{array}$ & $\begin{array}{l}\text { Obama and Emanuel publically announce efforts to reduce food deserts and the opening of new food } \\
\text { stores. }\end{array}$ & Corporation \\
\hline
\end{tabular}

The arrangement of supermarket focused events laid out in a timeline may suggest a connected sequence and a building momentum. Upon closer examination, however, evidence suggests a silo effect in which both public and corporation initiated efforts have occurred within a similar timeframe but in fact have no connection. Mari Gallagher of Gallagher Consulting, who worked as a consultant for Wal-Mart in its battles to enter the city, was on the city's grocery store task force in 2005 and 2006 (Heinzmann, 2011). Gallagher is credited with helping to popularize the concept of food deserts and has drafted various reports using mapping to show how strategically located stores might eliminate food deserts in Chicago (Gallagher, 2010, 2011). Yet these efforts were completely independent of the Philadelphia based Food Trust's publishing of The Need for More Supermarkets in Chicago (2008). The Food Trust's participation in Chicago was limited to initial efforts leading to the creation of the FFFI-modeled Illinois Fresh Food Fund. Beyond the contribution of a few studies and some strategy guidance, The Food Trust's participation ceased, perhaps to make way for another entity to lead the initiative. In Gallagher's case, involvement in Chicago was initially tied to contract jobs with Wal-Mart. Yet Gallagher's The Chicago 2011 Food Desert Drilldown suggests an independent effort on the part of the consulting group to continue advocacy to end food deserts.

Amid the public-initiated efforts, further fragmentation of policy concerns can be found with the research of the Illinois Advisory Committee, which reported to the U.S. Commission on Civil Rights in 2011. The committee's work had no apparent relation to any of the other policy efforts underway and spoke more to a deep concern with how the food access issue has been framed. Whereas other Chicago based policy efforts may have included mention of racial disparities as a component of food access issues, the Illinois Advisory Committee saw race as central. Because food deserts predominantly exist in African American communities, the committee framed problem of food deserts as a civil rights issue (Illinois Advisory Committee, 2011). The committee also took exception with the term food deserts, arguing that not only is there no clear definition of what the term means, but "based on the obesity epidemic in communities of color, scarcity of food is not the problem” (Illinois Advisory Committee, 2011, p. 29). The committee made several recommendations rooted in diversity awareness, expanding community development beyond just opening stores, and increasing efforts to end poverty and improve education. Though these ideas have merit, the absence of the Civil Rights frame in other food access policy efforts 
suggests that this was a sidebar conversation between the Illinois Advisory Committee and the U.S. Commission on Civil Rights.

None of these efforts and reports-from The Food Trust, Gallagher Consulting, or the Illinois Advisory Committee - has received any mention in policy efforts voiced by the City of Chicago, even though the city has been vocal about its interest in working with private grocery retail companies. In a private meeting with food store CEOs, Mayor Emanuel "promised to help fast-track paperwork and create incentives to open new stores grocery stores in underserved communities” (Eng, 2011, para 11). Mike Simmons, policy director for Mayor Emanuel, has been working with the retail chains "to put together packages of financial incentives, zoning amendments and other accommodations” to finalize deals to open new stores (Huber, 2011, para 6). Chicago’s approach in working with chain grocery stores has been to foster a win-win situation where the stores can make a difference and make money (Heinzman, 2011). Though Mayor Emanuel and the city have benefited from receiving publicity and praise from Michelle Obama for these efforts (Yaccino, 2011), there is no evidence yet of how Chicago's support of food retailers can be linked to the either the Illinois Fresh Food Fund or to any pending national fresh food financing initiative.

Among Chicago-based endeavors, it is the grocery retailer companies that have shown the largest efforts-corporation-initiated activities that have actually translated into new stores opening in underserved areas. In mid-2011 Wal-Mart opened the first of five planned Wal-Mart Express stores, which are less than one-tenth the size of a typical Wal-Mart superstore (Jones, 2011). Later in 2011, the Office of the Mayor of the City of Chicago announced retailer plans to open a total of 36 new stores, 19 expanded Walgreens stores and 17 traditional grocery stores from retailers such as Supervalu, Roundy's Supermarkets, Wal-Mart Stores, and Aldi’s Stores (City of Chicago, 2011). Retailers may be seeking their piece of the city’s win-win strategy by entering a new phase of grocery store growth.

By opening hundreds of stores in food deserts over the next several years, Wal-Mart, Walgreens, and Supervalu hope to not only increase food access and jobs and gain political favors but also counter negative U.S. sales growth of the last few years (Byfield-Green, 2011; Jones, 2011). And according to The Nation, “the retailer's newfound interest in food deserts is a public relations push designed to help it finally gain entry into lucrative urban markets from which it has long been excluded, thanks to grassroots opposition” (Huber, 2011, para 8). One food justice advocate argues that Wal-Mart is using the term food desert as a way to get into communities and bring more corporate control over the food system. Other food advocates argue that the USDA definition of food deserts "defines the problem in a way that means that only large grocery stores can solve it. It does not account for the grassroots food infrastructure, made up of food hubs, farmers’ markets, co-ops and farmstands” (Huber, 2011, para 11). 
Although Chicago based corporate efforts to bring supermarkets into underserved areas appear scattered and not unified, a few stores have opened, and others are pending. These corporation-initiated efforts are bringing results, but the evidence does not suggest that these efforts take the form of a coherent policy, as the features of Table 4 indicate. The full picture of what is taking place in Chicago may not become fully apparent until more of the stores have been in operation long enough to measure to impacts. Also, if further information is made available, other dimensions to the corporate-based efforts may be better understood.

Table 4

Corporation Based Efforts in Chicago

\begin{tabular}{|c|c|}
\hline $\begin{array}{l}\text { Strategy } \\
\text { Components }\end{array}$ & $\begin{array}{l}\text { Initiators: Wal-Mart, Walgreens, Supervalu, (other stores) } \\
\text { Policy Level: City based, Corporation initiated. } \\
\text { Policy Tools: Direct investment from stores. City sponsored } \\
\text { incentives, such as fast-tracking business licenses, zoning, tax breaks. }\end{array}$ \\
\hline Funding Stream & $\begin{array}{l}\text { Not clear. Most likely funding from stores. Perhaps tax breaks from } \\
\text { city. }\end{array}$ \\
\hline Viability & $\begin{array}{l}\text { Stores are opening, largely from the efforts of the stores themselves. } \\
\text { The City is also providing incentives. }\end{array}$ \\
\hline Duration & $\begin{array}{l}\text { Difficult to determine. Wal-Mart apparently has had its eye on } \\
\text { Chicago since at least } 2006 \text {, so an estimate could be } 5 \text { years. }\end{array}$ \\
\hline Scope & $\begin{array}{l}\text { Based on the information available, corporation based efforts in } \\
\text { Chicago will bring as many as } 36 \text { new stores. }\end{array}$ \\
\hline Cost-effectiveness & There is not enough information to determine this. \\
\hline Repeatability & $\begin{array}{l}\text { There is no clear initiative to repeat. Other cities could perhaps study } \\
\text { how Chicago has tried to make it easier for large grocery retailers to } \\
\text { open stores. }\end{array}$ \\
\hline
\end{tabular}

In closing the discussion of Chicago based policy efforts, the influence of the corporationinitiated efforts appears strongest. Wal-Mart, for example, has been trying for several years to bring stores into underserved Chicago. It would appear that those efforts are about to pay off. Yet it is also possible that Wal-Mart is benefitting from the national attention now given to food access policy. It is important to point out that Pennsylvania's FFFI program has thus far only funded “independent or small regional chains” not big chain superstores such as Wal-Mart (Huber, 2011). The Wal-Mart question can be problematic. Is the company merely opportunistic and this is just the latest campaign of Wal-Mart's 
constant-expansion/growth-business model in a down economy? Or should Wal-Mart be viewed as a valid agent of change in the overall efforts to eliminate food deserts and increase food access? Questions like these point to a complex scenario in which it is not clear whether social equity and capitalism are in harmony or conflict. However, from a practical perspective, people need to eat and will generally obtain food where it is available and based upon their means. The recent recession has been driving many shoppers to seek out dollar stores and other discount retailers. Wal-Mart, among other companies, feels it can compete by expanding its growth and reach in this market.

\section{New Orleans Fresh Food Retailer Initiative}

Reports vary slightly as to the severity of food access issues in New Orleans. According to Thomas (2011), New Orleans tops the list of America's worst urban food deserts, beating out Chicago and Atlanta, rated numbers two and three, respectively. The average grocery store in New Orleans serves 16,000 people - double the national average. As of 2011 only 20 grocery stores were in operation compared with the 30 stores that existed before Hurricane Katrina in 2005. The Food Trust issued a 2009 press release reporting that 19 supermarkets reopened post hurricane. A Fresh Food Retailer Initiative FAQ prepared by the Hope Enterprise Corporation stated that just 18 stores remained after Katrina and there were as many as 18,000 residents per store (2011). Whatever the number, fewer stores remained after Katrina hit in 2005. The number did not increase radically (if at all) in the following six or seven years. The Food Trust (2009), the Hope Enterprise Corporation (2011), and LifeCity (2011) all cite a 2007 Tulane University survey which found that nearly 60\% of low income residents had to drive more than three miles to reach a supermarket, and only half of those residents own a car. The fact is, there are not enough stores, they are far flung, and food access has been compromised.

The New Orleans Fresh Food Retailer Initiative (FFRI) was developed in response to postKatrina conditions and to reports such as the 2007 Tulane University survey. Stevens (2008) described the earliest efforts to create the initiative as originating with the Louisiana Recovery Authority's request that the U.S. Department of Housing and Urban Development reallocate \$500 million in CDBG (Community Development Block Grant) funds to a post-Katrina program called the Long Term Community Recovery Program. The request met with approval, thus increasing available funds to $\$ 700$ million to be made available to various Louisiana parishes. In 2009, the state of Louisiana approved \$7 million for the creation of the Fresh Food Retailers Initiative program in New Orleans. A LifeCity press release reported the program launch date of March 15, 2011 (LifeCity, 2011). The initial monies of \$7 million were categorized as Disaster Community Development Block Grant funds. Hope Enterprise Corporation has provided a 100\% match of these funds, bringing up the total to \$14 million (Hope Enterprise Corp., 2011). 
FFRI is administered by the Hope Enterprise Corporation (2011), a New Orleans based CDFI (community development financial institution), and The Food Trust, the Philadelphia based nonprofit largely responsible for initiating and managing Pennsylvania's successful FFFI program. The Food Trust evaluates applicant eligibility. Based on Hope Enterprise Corporation’s Program Overview (2011), eligibility requirements for retail grocery outlets and supermarkets include:

- Plans to locate in below average areas for food market sales and density (categorized as LMI or Low-to-Moderate Income Census Track).

- Minimum of $15 \%$ or 24 linear feet of store shelf-space (whichever is greater) dedicated to the sale of fresh produce.

- Plans to use loans (forgivable and low interest) for financing pre-development, site preparation, construction, equipment, staff training, security, or inventory.

- Participation with an Environmental Review conducted by the City to determine whether the retail project can be classified as exempt, categorically excluded, as requiring an Environmental Impact Statement, or in need of an Environmental Assessment. (Hope Enterprise Corporation, 2011)

As stated in HOPE’s FAQ, Program Guidelines, and Program Overview (2011), Hope Enterprise Corporation provides financial products in the form of either forgivable or interest-bearing loans to eligible supermarkets and grocery stores. Forgivable loans are available for up to $\$ 500,000$ per store. Stores receiving a combination of forgivable and interest-bearing loans can receive up to (but not exceed) $\$ 1,000,000$. On a case-by-case basis, stores may obtain additional funding through market-rate bearing loans from New Markets Tax Credits or private lenders.

Nine months after its launching, the FFRI program made its first loan. Its recipient, DaFresh Seafood and Produce, plans to open a store in the Central City neighborhood of New Orleans ("Mayor Landrieu,” 2011). According to the report, total opening cost for the DaFresh project will run \$249,040. FFRI is loaning $\$ 117,000$, just under half of the opening costs, with a forgivable amount set at $10 \%$. The store is expected to employ eight people. Beyond this initial loan, little information is available as to other projects that could potentially receive FFRI funds. The Central City Funders' Collaborative (2012) reported that approximately 30 loan applications have been submitted and there will be more awards made. More time is needed to allow the full impact of New Orleans' FFRI project to unfold.

The New Orleans FFRI program may face some challenges due to a post-Katrina drop in population, such as an $80 \%$ loss of population density in the Lower 9th Ward, according to 2010 Census data (Myers, 2012). This could pose a problem for opening grocery stores, which depend on a strong customer base. However, the occurrence of grocery "leakage” (when residents leave their neighborhood 
to shop for food) indicates that the population does have the spending power to support new stores (Myers, 2012). Also, there may be the hopeful logic that a grocery store would provide an anchor for a community and help draw people back.

Though it may be too early to assess the results of FFRI, the program does exhibit many effective policy features, as summarized in Table 5.

Table 5

New Orleans FFRI

\begin{tabular}{|c|c|}
\hline $\begin{array}{l}\text { Strategy } \\
\text { Components }\end{array}$ & $\begin{array}{l}\text { Initiators: Louisiana Recovery Authority } \\
\text { Policy Level: City based. } \\
\text { Policy Tools: Interest-bearing loans and forgivable loans. }\end{array}$ \\
\hline Funding Stream & $\begin{array}{l}\text { \$7 million in Disaster Community Development Block Grant Funds; } \\
\text { another matching } \$ 7 \text { million made available by Hope Enterprise } \\
\text { Corporation. }\end{array}$ \\
\hline Viability & $\begin{array}{l}\text { An effective program from the standpoint of the administering } \\
\text { partnership of Hope Enterprise Corporation and The Food Trust. } \\
\text { Hope Enterprise Corporation, a CDFI, provides funding and technical } \\
\text { assistance in financing. The Food Trust screens applicants for } \\
\text { eligibility. }\end{array}$ \\
\hline Duration & $\begin{array}{l}\text { Beginning with the Louisiana Recovery Authority's efforts to acquire } \\
\text { funding in } 2008 \text {, it took } 3 \text { years for the launching of FFRI in } 2011 \text {. } \\
\text { It took just } 9 \text { months for FFRI to fund its first project. }\end{array}$ \\
\hline Scope & Thus far, 1 store will open and employ 8 people. \\
\hline Cost-effectiveness & $\begin{array}{l}\text { If it cost FFRI } \$ 117,000 \text { to get a store open that will serve Central City } \\
\text { and create } 8 \text { jobs, then the benefits will far exceed the costs. }\end{array}$ \\
\hline Repeatability & $\begin{array}{l}\text { This program could be repeated elsewhere if there were active } \\
\text { participation of the state, funds obtain either federally or from the } \\
\text { state, a food-access savvy non-profit to help administer the program, } \\
\text { and a highly capable CDFI to handle financing. }\end{array}$ \\
\hline
\end{tabular}

Several factors and conditions influence the replicability of the New Orleans FFRI program. First, the state of Louisiana, through the LRA, advocated for federal funding. It is not typical for a state to seek federal funding on behalf of a city; usually a city would have to do its own legwork. But in this case, a natural disaster came very close to completely destroying New Orleans. The advent of hurricane Katrina and its debilitating after effects created a shared experience that galvanized the city and state. In other regions of the country, states may or may not be willing to advocate on behalf of a city when vying for federal funds. 
Another consideration of program repeatability entails organizational and programmatic capacity. Put plainly, a food financing program needs capable agents to implement and administer the program. Pennsylvania’s FFFI has The Food Trust and The Reinvestment Fund, a CDFI. New Orleans' FFRI program shares The Food Trust but has a local CDFI, Hope Enterprise Corporation. The Food Trust has had a hand in helping many cities sort through food access issues, but as a Philadelphia based organization, its resources and reach may only go so far. Other cities hoping to launch a similar food financing initiative may not be able to count on assistance from The Food Trust. Other cities would also need to identify a capable CDFI. Like many other forms of community based corporations, entities, and institutions, CDFIs have primarily focused on financing for housing and businesses other than supermarkets and grocery stores. In other words, though a CDFI may know about different loan products, it may not have any understanding of the supermarket industry and therefore not be confident with providing loans to supermarket projects. Both The Reinvestment Fund and Hope Enterprise Corporation understand the market particulars of working with supermarkets and grocery stores. New Orleans may not see food access problems disappear overnight. But with the FFRI program, there is great potential to bring stores into the communities that need them.

\section{Kansas City, Missouri}

Rather than designing or using policies expressly designated for financing food retail projects, policy makers in Kansas City have drawn from existing revitalization and economic development tools that most often take the form of TIF (tax incremental financing) plans. This section looks at the history of the Blue Parkway Sun Fresh grocery store development, an upcoming ALDI grocery store project, and initial plans for a community grocery store project initiated by Truman Medical/Hospital Hill Economic Development Corporation. As a TIF financed project, the downtown Cosentino's grocery store will be given brief mention, but as an upscale grocery store in proximity to corporate businesses as well as the gentrified and more affluent Crossroads District, Cosentino’s is not an example of a store that provides food access to an underserved community.

\section{TIF}

Each of the following cases involves tax increment financing, or TIF, projects. While this paper will not delve too deeply into all the complexities, a basic understanding of TIF will benefit the discussion. TIF first appeared in California in 1952 and was designed as a self-financing tool for redevelopment projects in blighted urban areas (Johnson, 2002). TIF allows for both financing and land development, making it an appealing tool for revitalization and redevelopment projects. Johnson (2002) described the TIF process as having five distinct, highly detailed stages of initiation, formulation, 
adoption, implementation, and evaluation/termination. The nuances of the financing are extremely complex, but in basic terms, TIF projects are financed by the tax revenues that the new development would generate, and administrators of a TIF project have discretion as to how the TIF funds can be allocated (Johnson, 2002). TIF plans have been used all over the country to finance development projects, and the application of TIF financing strategies varies depending on the region.

As applied in Kansas City, TIF projects have a few features. According to the Economic Development Corporation of Kansas City (n.d.), property owners make payments rather than property taxes for the life span of the TIF, which can be a maximum of 23 years. The payments are referred to as PILOTS, or Payments In Lieu Of Taxes. Additionally, the TIF reaps half of the revenue generated from the project. This revenue source, known as EATS or local Economic Activity Taxes, is derived from sales and earnings taxes. Eligible TIF projects need to be appropriately categorized as blighted, conservation, or economic development areas. A "but for" test is included in the TIF proposal and demonstrates that the project would not be feasible without the TIF assistance. In the three cases that follow, the site areas have been categorized as blighted (Economic Development Corporation of Kansas City, n.d.).

\section{Blue Parkway Sun Fresh}

According to the Shops on Blue Parkway website, this retail center, which includes a Sun Fresh grocery store, stands as the culmination of a 13-year development plan. For many people involved in Kansas City community development, the mention of the Blue Parkway Shops evokes comments on the project's extensive challenges and timeline. The Blue Parkway story is not well documented. What information exists is buried in planning documents, annual reports, and a few news stories. Any institutional memory that may exist for the project has begun to vanish, as the developing organizations themselves have changed over the years. The Blue Parkway website features a defunct logo and link to Swope Community Builders, the organization known as the developer of the Blue Parkway retail center. Swope Community Builders can be appropriately located at SwopeCommunityBuilders.org, but there is little information at this website on the Blue Parkway project. Such informational disconnects pervade the entire project narrative.

Internet and database queries for terms such as "Blue Parkway Shops," "Sun Fresh,” and "Swope Community Builders" yielded few results, primarily because of inconsistent nomenclature in the project name, which has changed many times. A 2004 Swope Community Builders Annual Report refers to the Shops on Blue Parkway as "the final piece of the Mount Cleveland Initiative begun in 1991” (Swope Community Enterprises, 2004, p. 12). A local report of City Council actions notes approval of a Blue Parkway Development Project (“Kansas City Council," 1992). Elsewhere, the project is dubbed the Blue Parkway Plan, in reference to Blue Parkway Area General Development Plan (Brush Creek Corridor TIF, 
1999). In 1999, the Tax Increment Financing Commission of Kansas City approved the Brush Creek Corridor Tax Increment Financing Plan, which included four redevelopment project areas in various locations in relation to Blue Parkway. Not only has the project name morphed but so has the name of its primary developer. The entity that drafted the proposal was Midtown Community Development Corporation, which did business as Community Builders of Kansas City. Community Builders later became Swope Community Builders.

These name changes point to an underlying disorganization with the Blue Parkway Shops project that may have contributed to delays in the opening of the Blue Parkway Sun Fresh grocery store. How long did it take to get Sun Fresh open at the Blue Parkway Shops? Answers vary. One response is 16 years, from the 1991 Mount Cleveland Initiative to 2007, when Sun Fresh opened its doors (Swope Community Enterprises, 2004, 2007). Or, if counting from 1999, when the Brush Creek Corridor TIF was approved, eight years, although the TIF was amended seven times in as many years. A final answer is two years, from 2005 when the Shops on Blue Parkway opened and included a Baron's Supermarket to 2006, when a Sun Fresh replaced Baron's (Swope Community Enterprises, 2004, 2006). A definitive answer is difficult to determine.

One significant aspect of this case study is that although a grocery store was an important feature of the Blue Parkway project, it was not the sole focus. According to Exhibit 3 of the Brush Creek Corridor TIF, the overall plan was to create a total of 11,000 square feet of retail space and 1100 new jobs, stabilize the surrounding neighborhoods, leverage both public and private investments, and enhance the tax base (Brush Creek Corridor Tax Increment Financing Plan, 1999, p. 27). If the seven TIF amendments are any indication, lengthy project delays could be attributed to additions to the project boundaries and several increases in estimated project costs.

Chuck Gatson, formerly a senior development specialist for the Community Builders of Kansas City, attributes the project's delays to the grocery industry's assumptions regarding race and urban areas. In Gatson's view of the development plan, the grocery store was seen as the catalyst and draw to the retail center. However, local wholesaler Associated Wholesale Grocers (AWG) did not believe a store would be successful in that area. AWG based this opinion on an outmoded market analysis that did not take into account actual local incomes. AWG viewed the development area as a black site and assumed that the local incomes would not support a grocery store (C. Gatson, personal communication, April 12, 2012).

The first grocery retailer at Blue Parkway was Baron’s, a Lawrence, Kansas, owned business. In Lawrence, Baron's has been very successful. Gatson was not sure why the store left but suspects it had something to do with leasing issues. He also thought that Swope Enterprises leadership issues had some bearing, as the changes in leadership brought in people who did not fully understand retail and grocery related developments. Gatson framed the problems of drawn out delays and obstacles to the Blue Parkway 
Shops and related grocery store project as a grocery industry reluctance to develop in minority areas. The AWG market model is based on stores of 40 to 75 thousand square feet. Gatson said that store operators using a "limited access store” model have generally been more comfortable opening stores in urban areas. Limited access stores are smaller, running between 10 and 25 thousand square feet, and they offer fewer goods. Because limited access stores operate at a smaller scale and lower volume, they can react more quickly and adapt to local market needs (what local people are demanding) in ways that the larger AWG model cannot. He mentioned stores such as Sav-A-Lot and ALDI as examples of limited access stores (C. Gatson, personal communication, April 12, 2012).

Though the TIF plan and project development process was lengthy and complicated, the east Kansas City neighborhood has had continued access to the Blue Parkway Sun Fresh since 2007. If people were not shopping there, the store would not have remained open. Due the complexities of this case study, the Blue Parkway Sun Fresh project does not conveniently fit into the policy feature table used in the previous case studies throughout this paper. When judging the merits of the project by its viability (extremely complicated to implement), duration (it took the better part of 16 years to implement), or scope (for all costs, efforts, and time, the outcome is one store), the Blue Parkway Sun Fresh does not seem like a much of an outcome for all that went into the project. Yet, without some form of financial assistance, no grocery store would have entered the area. The Sun Fresh remains in operation and employs 12 people (Manta, 2012). People’s lives have no doubt been made better by this change in food access. This impact needs to be appreciated and understood when evaluating this project.

\section{ALDI at 39th and Prospect}

According Petrina Gooden, assistant to 3rd District Councilman Jermaine Reed, the construction of a new ALDI store at 39th and Prospect is expected to begin soon and reach completion sometime in 2012 (City of Kansas City, 2012; P. Gooden, personal communication, April 5, 2012). The origins of the ALDI project begin in 2005 when the City Council voted to approve a \$125,000 contract with Swope Community Builders Inc. to develop a TIF plan and planning study for the 39th and Prospect area (“City Council actions,” 2005, para. 26). The plan addressed a 17.41 acre plat that would to be divided into four adjoining redevelopment project areas. A new ALDI store was planned for Project Area 1 at the northwest corner of 39th Street and Prospect Avenue (see figure below), and this would serve as an anchor for housing developments to go into Project Areas 2 through 4. The ALDI store would occupy 16,558 square feet and cost just under \$5 million to build. According to the plan, without the TIF, the IRR (initial rate of return), or expected cash flows, of the completed ALDI project would be $2.64 \%$. Analysis demonstrated that with the TIF, the IRR would be $6.66 \%$, much closer to the market rate of $7 \%$ or $8 \%$ for similar developments (39th \& Prospect Tax Increment Financing Plan Kansas City, 2006, p. 9). 


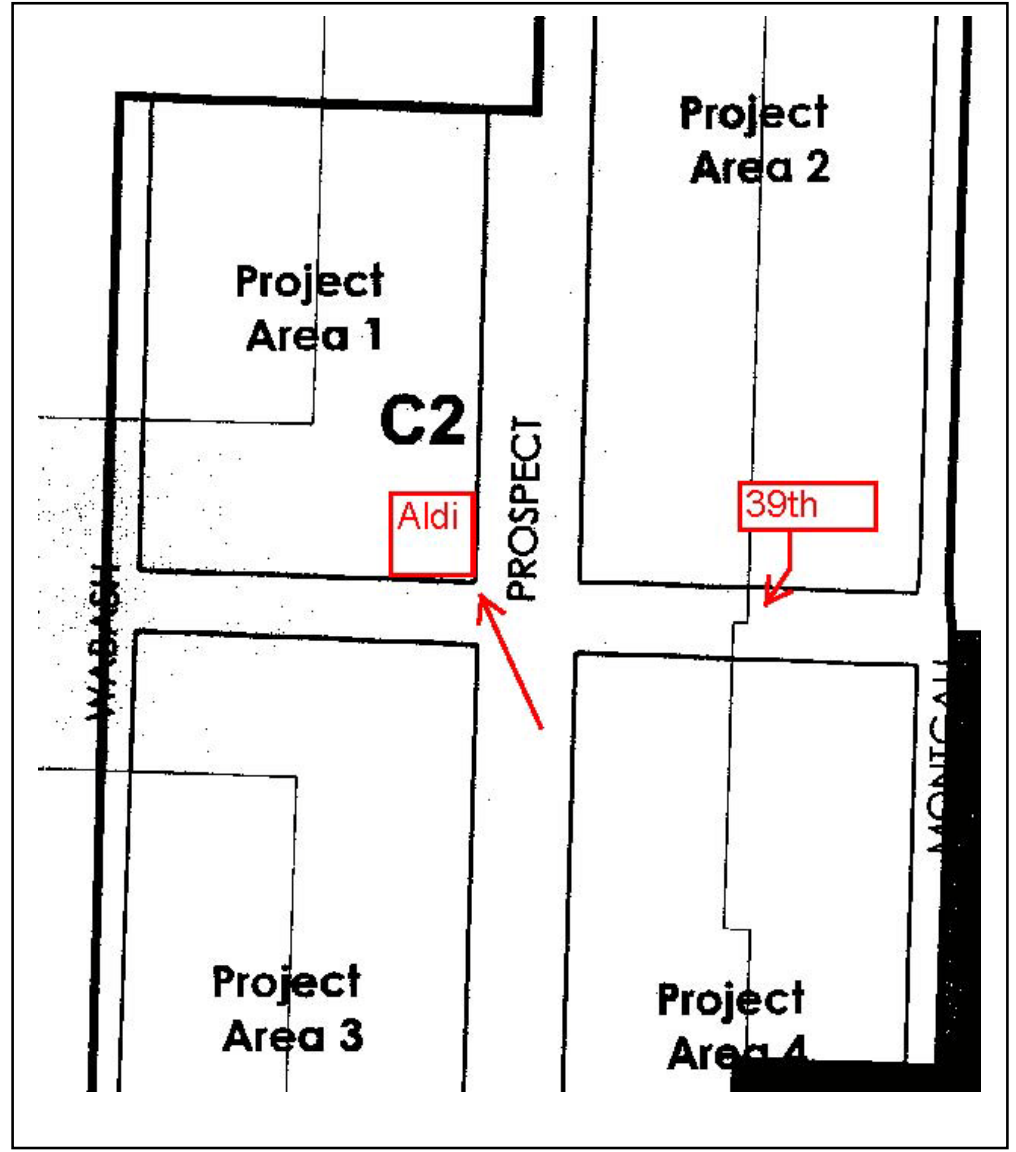

(Excerpted from 39th \& Prospect Tax Increment Financing Plan Kansas City, 2006.)

The final TIF plan met with TIF Commission and City Council approval in 2006. According to the TIF Plan, store construction was to be completed by fall 2007 (39th \& Prospect Tax Increment Financing Plan Kansas City, 2006, p. 33). Though the reasons are unclear, the project met with delays. Four years later in a press conference (“City Announces,” 2011; City of Kansas City, 2011) 3rd District Council representatives announced that construction of the ALDI store would begin in the winter of 2011 and be completed by summer 2012. Winter 2011 came and went and construction did not begin. Though the ALDI was to be built first, its construction delays were tied to a $\$ 625,000$ cap set for the initial housing planning for the remaining project areas. In March of 2012, the City Council voted to life the cap set by the original TIF ordinance and approved additional TIF funds for the original plan (P. Gooden, personal communication, April 5, 2012). With the approval of what is now billed as the Super TIF, construction of the ALDI store will soon begin and is expected to be completed sometime in 2012.

A few possibilities may account for the delays in the ALDI construction. Because the ALDI project is part of a larger TIF community development project, the ALDI corporation most likely felt the success of the new store would depend on the surrounding developments. The ALDI construction was 
slated to be first, following by the housing development projects. Yet, if the housing development phase met with hang-ups due to a funding cap in the original TIF, this might account for ALDI's reluctance to begin store construction. It is also possible that TIF amendments have been prepared but are not yet posted on the EDC-KC website. Though the ALDI store will follow a limited access store model and already has a few other stores in other Kansas City urban areas, ALDI may have doubts that existing surrounding neighborhoods can support the store. It remains to be seen whether changes to the original TIF ordinance will influence ALDI to begin store construction in 2012.

\section{Truman Medical Center Community Grocery Store}

In response to what it perceives as Kansas City’s urban food deserts problem, Truman Medical Centers (TMC) announced plans to build a grocery store in the urban core (Bluford, 2011). TMC points to food deserts and limited food access to fresh healthy foods as a major health concern. The impetus to enter the grocery business is to improve the health of people in underserved urban communities (Hospital Hill Economic Development Corporation, n.d.). To prepare for this venture, TMC held several meetings with community residents to seek their input on what they want in a new store (Ferrell, 2012). Public feedback called for food that is fresh and affordable, including produce, meats, and organic choices (Oberholtz \& Lee, 2012).

As of this writing, very few store details have been made available. Though an operator has not been named, the selected store site is a vacant corner lot at 27th Street and Troost Avenue. The store would open sometime in 2013 (Ferrel, 2012; Oberholtz \& Lee, 2012). Ranging between 30 and 40 thousand square feet, the store will have nutritionists on staff and will attempt to carry goods from local farmers and businesses (Hospital Hill Economic Development Corporation, n.d.). TMC is partnering with the Hospital Hill Economic Development Corporation (HHEDC) for this project.

According to HHEDC, TMC is relying on a business venture rationale based on the views of grocery industry specialists. Expectations that the new store will succeed and bring as many as 175 jobs to the area are based on a market analysis, which has not been made public. Stevenson has argued that a proper analysis and understanding of the surrounding communities would show that the proposed grocery store will not be able to stay in operation without continued support through subsidies (R. Stevenson, class lecture, April 11, 2012). As to financing strategies, Gatson has proposed that it will entail a combination of a Super TIF, New Market Tax Credits, and other city subsidies (C. Gatson, personal communication, April 12, 2012). The TMC Community Grocery Store project raises many questions that current information cannot yet answer. As with the other Kansas City case studies, this project may also meet with delays and obstacles. 
An assessment of the Kansas City projects discussed here presents a challenge. Even in aggregate, the cases do not present a set of impressive looking outcomes when framed in the context of the seven-feature policy table. The TMC community grocery store project, for example, is still in its infancy and bears too few facts. Within these limitations, the Table 6 attempts to summarize features of TIF related grocery store projects in Kansas City.

Table 6

Kansas City TIF Grocery Store Projects

\begin{tabular}{|c|c|}
\hline $\begin{array}{l}\text { Strategy } \\
\text { Components }\end{array}$ & $\begin{array}{l}\text { Initiators: Swope Community Developers } \\
\text { Policy Level: Community based. } \\
\text { Policy Tools: TIF }\end{array}$ \\
\hline Funding Stream & $\begin{array}{l}\text { TIF revenues from PILOTS (Payment in Lieu of Taxes) and EATs, (Economic } \\
\text { Activity Taxes). }\end{array}$ \\
\hline Viability & $\begin{array}{l}\text { TIF plans are useful in that they allow for flexible combinations of } \\
\text { financing and land development. But they are very complex, time } \\
\text { consuming, and based on assumptions of future worth }\end{array}$ \\
\hline Duration & $\begin{array}{l}\text { Counting from the first plans in } 1991 \text { to the opening in 2007, the Blue } \\
\text { Parkway Sun Fresh project took } 16 \text { years. } \\
\text { Though construction has yet to begin, the ALDI project has taken at least } 7 \\
\text { years so far. }\end{array}$ \\
\hline Scope & $\begin{array}{l}\text { Drawing solely from the KCMO cases discussed, } 1 \text { store has been } \\
\text { completed (Sun Fresh) which employs } 12 \text { people. } \\
\text { (Another TIF project store not discussed in this analysis is the downtown } \\
\text { Cosentino's) }\end{array}$ \\
\hline Cost-effectiveness & Without better transparency of reports, this can't be assessed. \\
\hline Repeatability & $\begin{array}{l}\text { The success of using a TIF plan to develop a supermarket would depend } \\
\text { on many factors, such as the condition of the proposed site, the } \\
\text { capabilities of the CDC backing the TIF proposal, the capability of local } \\
\text { incomes to support a store, the potential concerns that a grocery operator } \\
\text { may have in opening in an urban area, to name a few. If these and other } \\
\text { challenges could be addressed, then a TIF backed grocery store project } \\
\text { could be repeated elsewhere. }\end{array}$ \\
\hline
\end{tabular}

It may be overstating the point, but this seven policy feature framework may not fairly capture the full value and impact of Kansas City policy efforts. In the following section, other factors will be 
considered that may provide a more comprehensive way to consider the efficacy of TIF based grocery store projects.

\section{Part Five: Meta-Analysis, Policy Comparison, Repeatability, Effectiveness}

Though some analysis occurred within each case study, the policies need to be viewed from a broader perspective. This section will attempt to provide a meta-analysis by comparing the components of the case studies and evaluating the overall effectiveness of the policies.

\section{Case Study Comparison}

To begin the meta-analysis, the discussion will first compare the five case studies through each of the seven policy features:

- $\quad$ Strategy Components (Initiators, Policy Level, and Policy Tools)

- $\quad$ Funding Stream

- Viability (how easy/complicated is it to implement?)

- Duration (how long does it take to enact?)

- $\quad$ Scope (what kind of impact, how many stores?)

- Cost-effectiveness

- Repeatability (can it be replicated elsewhere?)

The first two features, Strategy Components and Funding Stream, speak to policy mechanics—what the policies were and how they worked. Viability, Duration, Scope, and Cost-Effectiveness address outcomes and impacts of the policies. All six of these features help answer the question of Repeatability—which policies would work elsewhere?

In quantitative data analysis, discussions focus on high, low, and median data points rather than every single piece of data. The data in this analysis is predominantly qualitative and can be judged in ways approximating high, low, and median ratings. This comparison discussion will not chronicle every detail from each case study but instead identify the policy features that appeared to be the strongest, weakest, and average of the cases, as shown in the following charts. 
Policy Feature 1: Strategy Components

\begin{tabular}{|c|c|c|c|c|}
\hline Liberty City & $\begin{array}{l}\text { Pennsylvania's } \\
\text { Fresh Food } \\
\text { Financing Initiative }\end{array}$ & $\begin{array}{l}\text { Illinois Fresh Food } \\
\text { Fund \& Chicago } \\
\text { Efforts }\end{array}$ & $\begin{array}{l}\text { New Orleans Fresh } \\
\text { Food Retailer } \\
\text { Initiative }\end{array}$ & Kansas City Efforts \\
\hline $\begin{array}{l}\text { Initiators: Otis Pitts, } \\
\text { LISC, TEDC. } \\
\text { Policy Level: } \\
\text { Community base } \\
\text { Policy Tools: Public } \\
\text { Investments to } \\
\text { Leverage Private } \\
\text { Partnership \& } \\
\text { Investment Tax } \\
\text { Credits. }\end{array}$ & $\begin{array}{l}\text { Initiators: The Food } \\
\text { Trust, State } \\
\text { Representatives. } \\
\text { Policy Level: } \\
\text { Statewide. } \\
\text { Policy Tools: } \\
\text { Financing via Direct } \\
\text { Grants, Core Fund } \\
\text { Loans, New Market } \\
\text { Tax Credits. }\end{array}$ & $\begin{array}{l}\text { Initiators: The Food } \\
\text { Trust \& the Illinois } \\
\text { Food Marketing } \\
\text { Task Force } \\
\text { Policy Level: } \\
\text { Statewide. } \\
\text { Policy Tools: Direct } \\
\text { Loans \& Grants. } \\
\text { Financial leveraging. } \\
\text { Initiators: Wal-Mart, } \\
\text { Walgreens, } \\
\text { Supervalu, (other } \\
\text { stores) } \\
\text { Policy Level: City } \\
\text { based, Corporation } \\
\text { Initiated. } \\
\text { Policy Tools: Direct } \\
\text { investment from } \\
\text { stores. City } \\
\text { sponsored } \\
\text { incentives, such as } \\
\text { fast-tracking } \\
\text { business licenses, } \\
\text { zoning, tax breaks. }\end{array}$ & $\begin{array}{l}\text { Initiators: Louisiana } \\
\text { Recovery Authority. } \\
\text { Though not an } \\
\text { initiator, The Food } \\
\text { Trust plays major } \\
\text { role in administering } \\
\text { the program. } \\
\text { Policy Level: City } \\
\text { based. } \\
\text { Policy Tools: } \\
\text { Interest-bearing } \\
\text { loans and forgivable } \\
\text { loans. }\end{array}$ & $\begin{array}{l}\text { Initiators: Swope } \\
\text { Community } \\
\text { Builders; Truman } \\
\text { Medical Centers } \\
\text { Policy Level: } \\
\text { Community based. } \\
\text { Policy Tools: TIF }\end{array}$ \\
\hline
\end{tabular}

The initiator with the strongest influence was The Food Trust, the non-profit food advocacy group largely responsible for the existence of Pennsylvania’s FFFI. The Trust had the most breadth in understanding food access issues and effectively used data-drive reports for advocacy and consensus building. Also, the Trust had a strong presence in three of the five cases, making it the premier foodaccess advocacy group / administrative entity. The weakest initiator model is that of the single person advocate as was the case with Otis Pitts in Liberty City. Mr. Pitts was by no means a weak person and in fact demonstrated impressive leadership. Yet, the role he played, the deep community knowledge he brought to the project, and the force of his personality and efforts were unique to him and would not be easily replicable. All other initiator models — the efforts of private companies in Chicago, the Louisiana Recovery Authority, and Swope Community Builders_acted within the unique conditions of their environments, and one model does not stand out as a superior or inferior initiator model.

The statewide policy level of FFFI had the most reach and impact; based on the FFFI case, the statewide policy model is the strongest. Some of these details will be iterated in sections below. Oddly enough, the statewide model also proved to be the weakest, least effective model as evidenced in the 
Illinois Fresh Food Fund. Thus far, the corporation-based efforts appear to be bringing in stores, though these efforts have less to do with retail intervention policies than market-driven motivations. As of this writing, the city-based efforts of New Orleans are in early stages that show promise, with one funded store project and many proposals under review. The local efforts that occurred in Liberty City and Kansas City both reflect the challenges for community-based policies that can result in project delays.

In terms of policy tools, FFFI's direct grants and loans have been the strongest. The limbo status of the Illinois Fresh Food Fund renders its plan for direct grants and loans ineffectual and therefore the weakest set of policy tools. The New Orleans Fresh Food Retailor Initiative’s interest-bearing and forgivable loan tools are well positioned, but the momentum is still building. The leveraging of public and private funds in Liberty City did produce a success, but these tools depended on complex and political relationship building. A policy tool with multiple purposes for land, property, and housing development as well as financing in Kansas City TIFs are too complex and cumbersome for the purposes of focused retail intervention policy.

Policy Feature 2: Funding Stream

\begin{tabular}{|c|c|c|c|c|}
\hline Liberty City & $\begin{array}{l}\text { Pennsylvania's } \\
\text { Fresh Food } \\
\text { Financing Initiative }\end{array}$ & $\begin{array}{l}\text { Illinois Fresh Food } \\
\text { Fund \& Chicago } \\
\text { Efforts }\end{array}$ & $\begin{array}{l}\text { New Orleans Fresh } \\
\text { Food Retailer } \\
\text { Initiative }\end{array}$ & Kansas City Efforts \\
\hline $\begin{array}{l}\text { Multi-sourced: } \\
\text { LISC \$250K; City } \\
\text { \$650K; Dade County } \\
\text { \$260K; Econ. Dev. } \\
\text { Admin. (Federal) } \\
\text { \$800,000; City } \\
\text { Business Leaders } \\
\text { \$250K; Winn Dixie } \\
\text { \$2 million. }\end{array}$ & $\begin{array}{l}\text { \$30 million in state } \\
\text { seed money. } \\
\$ 165 \text { million from } \\
\text { TRF in leverage } \\
\text { private investments. } \\
\text { TRF received } 3 \\
\text { NMTC allocations } \\
\text { totaling \$278.5 } \\
\text { million. }\end{array}$ & $\begin{array}{l}\text { Ill: \$10 million in } \\
\text { state seed money. } \\
\text { Chicago: Not clear. } \\
\text { Most likely funding } \\
\text { from stores. Perhaps } \\
\text { tax breaks from city }\end{array}$ & $\begin{array}{l}\text { \$7 million in } \\
\text { Disaster Community } \\
\text { Development Block } \\
\text { Grant Funds; } \\
\text { another matching \$7 } \\
\text { million made } \\
\text { available by HOPE. }\end{array}$ & $\begin{array}{l}\text { TIF revenues from } \\
\text { PILOTS (Payment in } \\
\text { Lieu of Taxes) and } \\
\text { EATs, (Economic } \\
\text { Activity Taxes). }\end{array}$ \\
\hline
\end{tabular}

Again, FFFI stands as the strongest funding stream model. Though this is not the only case study to feature state seed money, FFFI's state seed funds were the largest and leveraged for the most financial impact. Illinois Fresh Food Funds remain unallocated and as a result have not been leveraged in any way, earning this the category of weakest funding stream model. Funding streams for Chicago's corporationinitiated projects lack transparency; beyond the fact that many stores are opening, the efficacy of the funding model is difficult to judge. The Liberty City funding stream model shows that a multi-sourced funding project is possible, but this was a hard-won project. It does not provide a readily transferrable funding template that can be repeated elsewhere. The Kansas City TIF model has worked, and it is arguably the funding model with which Kansas City community developers are most familiar and 
comfortable. Yet because many parties are involved and funding is based on estimated/project property tax values, this is a challenging model to implement and administer.

\section{Policy Feature 3: Viability}

\begin{tabular}{|c|c|c|c|c|}
\hline Liberty City & $\begin{array}{l}\text { Pennsylvania's } \\
\text { Fresh Food } \\
\text { Financing Initiative }\end{array}$ & $\begin{array}{l}\text { Illinois Fresh Food } \\
\text { Fund \& Chicago } \\
\text { Efforts }\end{array}$ & $\begin{array}{l}\text { New Orleans Fresh } \\
\text { Food Retailer } \\
\text { Initiative }\end{array}$ & Kansas City Efforts \\
\hline $\begin{array}{l}\text { Details of exactly } \\
\text { how investors were } \\
\text { persuaded and } \\
\text { secured are not } \\
\text { clear. Given that } \\
\text { initial efforts of City } \\
\text { businesses and } \\
\text { Federal funds failed } \\
\text { to produce results, } \\
\text { the challenge to } \\
\text { Pitts and TEDC was } \\
\text { likely enormous and } \\
\text { difficult to } \\
\text { implement the } \\
\text { processes. }\end{array}$ & $\begin{array}{l}\text { State involvement } \\
\text { likely due to } \\
\text { advocacy, } \\
\text { organization, efforts } \\
\text { \& partnerships of } \\
\text { The Food Trust. } \\
\text { Financing is } \\
\text { complex, but TRF, a } \\
\text { CDFI, can manage } \\
\text { the financing } \\
\text { processes. }\end{array}$ & $\begin{array}{l}\text { III. FFF - Without the } \\
\text { advocacy, } \\
\text { organization, efforts } \\
\text { \& partnerships of } \\
\text { the Food Trust, the } \\
\text { State may not have } \\
\text { allocated funds. } \\
\text { The project current } \\
\text { lacks advocacy- } \\
\text { based leadership. } \\
\text { No CDFI has } \\
\text { emerged to } \\
\text { managing financing. } \\
\text { Chicago: Stores are } \\
\text { opening, largely } \\
\text { from the efforts of } \\
\text { the stores } \\
\text { themselves. The City } \\
\text { is also providing } \\
\text { incentives. }\end{array}$ & $\begin{array}{l}\text { An effective } \\
\text { program from the } \\
\text { standpoint of the } \\
\text { administering } \\
\text { partnership of Hope } \\
\text { Enterprise } \\
\text { Corporation and The } \\
\text { Food Trust. Hope } \\
\text { Enterprise } \\
\text { Corporation, a CDFI, } \\
\text { provides funding } \\
\text { and technical } \\
\text { assistance in } \\
\text { financing. The Food } \\
\text { Trust screens } \\
\text { applicants for } \\
\text { eligibility. }\end{array}$ & $\begin{array}{l}\text { TIF plans are usefu } \\
\text { in that they allow } \\
\text { for flexible } \\
\text { combinations of } \\
\text { financing and land } \\
\text { development. But } \\
\text { they are very } \\
\text { complex, time } \\
\text { consuming, and } \\
\text { based on } \\
\text { assumptions of } \\
\text { future worth. }\end{array}$ \\
\hline
\end{tabular}

Viability speaks to level of ease or complication involved with implementing a policy. No case stands out as having a particularly easy policy model, and in fact all were complicated and challenging in different ways. Pennsylvania's FFFI and New Orleans' Fresh Food Retailer Initiative are the most viable models for a few reasons. First, these are policies specifically designed for retail intervention and food access. TIF, for example, is primarily designed to address economic development and revitalization, as in Kansas City, where grocery stores have been factored into larger redevelopment plans. This increases the possibility for delays on the grocery store portion of a TIF plan because the market analysis required for grocery stores differs from the market analysis required in assessing property values. A proposed grocery store deemed viable in a TIF proposal market analysis might actually be shown to be unfeasible in a grocery/supermarket-based market analysis conducted for an FFFI or FFRI proposal. Another reason that FFFI and FFRI are more viable is that, through direct grants and loans, they can provide funds up front, and this is a big advantage in helping a store offset development and opening costs. TIF funds would come later at a future point in a TIF project. Funding to cover development and opening costs would 
initially need to come from the store operator or some other loan mechanism. Finally, FFFI and FFRI both have levels of agency that make the policies viable. Specifically, they both benefit from The Food Trust expertise in handling policy implementation, community advocacy, project proposal screening, and administration. They also each have a capable CDFI (community development financial institution) to handle the financial components. FFFI has The Reinvestment Fund (TRF) to handle grants and loans. The FFRI has the Hope Enterprise Corporation (HOPE) to create interest bearing and forgivable loans. A major reason that the Illinois Fresh Food Fund is stagnating is that there is neither an administrative advocacy group nor a CDFI in place to run a program and allocate funds. Thus, having the appropriate agents in place helps ensure that a policy actually does something.

\section{Policy Feature 4: Duration}

\begin{tabular}{|c|c|c|c|c|}
\hline Liberty City & $\begin{array}{l}\text { Pennsylvania's } \\
\text { Fresh Food } \\
\text { Financing Initiative }\end{array}$ & $\begin{array}{l}\text { Illinois Fresh Food } \\
\text { Fund \& Chicago } \\
\text { Efforts }\end{array}$ & $\begin{array}{l}\text { New Orleans Fresh } \\
\text { Food Retailer } \\
\text { Initiative }\end{array}$ & Kansas City Efforts \\
\hline $\begin{array}{l}\text { From the time TEDC } \\
\text { was founded in } \\
1982 \text {, it took } 3 \text { years } \\
\text { get Winn Dixie in } \\
\text { and open by } 1985 \text {. } \\
\text { It would be } 5 \text { years } \\
\text { when included the } \\
\text { failed efforts } \\
\text { starting in } \\
\text { 1980.Counting from } \\
\text { Food Trust's initial } \\
\text { efforts in 2001, it } \\
\text { took } 9 \text { years. }\end{array}$ & $\begin{array}{l}\text { Based on creation } \\
\text { in } 2004 \text { \& approved } \\
\text { funding for } 93 \\
\text { applications in 2010, } \\
\text { FFFI took } \\
6 \text { years to } \\
\text { implement. } \\
\text { Counting from Food } \\
\text { Trust's initial efforts } \\
\text { in 2001, it took } 9 \\
\text { years. }\end{array}$ & $\begin{array}{l}\text { Ill. If count the first } \\
\text { reporting efforts } \\
\text { from } 2005, \text { it took } \\
\text { nearly } 4 \text { years for } \\
\text { the creation of the } \\
\text { Illinois Fresh Food } \\
\text { Fund. Counting from } \\
\text { the Food Trust's first } \\
\text { report in } 2008 \text {, it } \\
\text { took a little over } 1 \\
\text { year. If we average } \\
\text { these, we could } \\
\text { estimate } 2.5 \text { years. } \\
\text { Chicago: Difficult to } \\
\text { determine. Wal- } \\
\text { Mart apparently has } \\
\text { had its eye on } \\
\text { Chicago since at } \\
\text { least } 2006, \text { so an } \\
\text { estimate could be } 5 \\
\text { years. }\end{array}$ & $\begin{array}{l}\text { Beginning with the } \\
\text { Louisiana Recovery } \\
\text { Authority's efforts } \\
\text { to acquire funding in } \\
2008 \text {, it took } 3 \text { years } \\
\text { for the launching of } \\
\text { FFRI in } 2011 . \\
\text { It took just } 9 \text { months } \\
\text { for FFRI to fund its } \\
\text { first project. }\end{array}$ & $\begin{array}{l}\text { Counting from the } \\
\text { first plans in } 1991 \text { to } \\
\text { the opening in } 2007 \text {, } \\
\text { the Blue Parkway } \\
\text { Sun Fresh project } \\
\text { took } 16 \text { years. } \\
\text { Though construction } \\
\text { has yet to begin, the } \\
\text { ALDI project has } \\
\text { taken at least } 7 \\
\text { years so far. }\end{array}$ \\
\hline
\end{tabular}

New Orleans' FFRI has had the shortest duration with just four years, counting from initial policy creation efforts to first funded project. There are likely several reasons for this. First, FFRI was borne out of post-Katrina conditions which influenced the coordination of federal, state, and city level efforts. Also, FFRI had the benefit of FFFI's trail-blazing, a successful model to follow, and FFFI's effective food policy advocate and administrative entity, The Food Trust. The fact that New Orleans is rated as the city with the worst food desert problem also makes the short duration extremely important. 
It took 16 years for the Blue Parkway Sun Fresh project to be completed. Changes in the TIF proposal cost estimates and project boundaries resulted in seven amendments over a seven-year period. Further project delays may have had to do with trying to find an operator to enter the project. Delays might also be attributed to the fact that TIF is not designed specifically for the supermarket/grocery industry and thus does not have the appropriate measures and assessments needed to appropriately predict the success of proposed stores. A project with a mid-range duration would be Wal-Mart's efforts to open new stores in urban areas of Chicago. The duration of five years began with the use of a private contractor to conduct an analysis of market potential and food-desert reduction and concluded with City announcements of planned store openings.

Policy Feature 5: Scope

\begin{tabular}{|c|c|c|c|c|}
\hline Liberty City & $\begin{array}{l}\text { Pennsylvania's } \\
\text { Fresh Food } \\
\text { Financing Initiative }\end{array}$ & $\begin{array}{l}\text { Illinois Fresh Food } \\
\text { Fund \& Chicago } \\
\text { Efforts }\end{array}$ & $\begin{array}{l}\text { New Orleans Fresh } \\
\text { Food Retailer } \\
\text { Initiative }\end{array}$ & Kansas City Efforts \\
\hline $\begin{array}{l}\text { Edison Plaza } \\
\text { Shopping Center, } \\
48,000 \text { sqft. cost } \\
\$ 2.1 \text { million to build. } \\
\text { Created } 135 \text { jobs \& } \\
\text { served } 12,000 \text { to } \\
17,000 \text { customers } \\
\text { per week. }\end{array}$ & $\begin{array}{l}88 \text { fresh-food retail } \\
\text { projects, spanning } \\
34 \text { counties. } \\
5000+\text { jobs } \\
\text { created/preserved } \\
\text { Increased food } \\
\text { access for more a } \\
\text { half-million people. }\end{array}$ & $\begin{array}{l}\text { Ill. FFF - There is not } \\
\text { enough information } \\
\text { to determine the } \\
\text { scope of the } \\
\text { initiative. The idea } \\
\text { was that it would } \\
\text { grow and be a } \\
\text { statewide program. } \\
\text { Based on the } \\
\text { information } \\
\text { available, } \\
\text { corporation based } \\
\text { efforts in Chicago } \\
\text { will bring as many as } \\
36 \text { new stores. }\end{array}$ & $\begin{array}{l}\text { Thus far, } 1 \text { store will } \\
\text { open and employ } 8 \\
\text { people. }\end{array}$ & $\begin{array}{l}\text { Drawing solely from } \\
\text { the KCMO cases } \\
\text { discussed, } 1 \text { store } \\
\text { has been completed } \\
\text { (Sun Fresh) which } \\
\text { employs } 12 \text { people. } \\
\text { (Another TIF project } \\
\text { store not discussed } \\
\text { in this analysis is the } \\
\text { downtown } \\
\text { Cosentino's) }\end{array}$ \\
\hline
\end{tabular}

FFFI boasts the greatest demonstrable impact with the opening of 88 store projects. It is too soon to judge the scope of New Orleans’ FFRI, but it is off to a good start and would be worth monitoring over time to see how well it follows in FFFI's footsteps. The activity in Chicago is impressive, with 36 stores planning to open soon. The scope of these efforts reflects in large part the efforts of private companies, Wal-Mart, Walgreens, and Supervalu. At first glance, Liberty City and Kansas City do not appear to have had a large impact. But Liberty City's success is consistent with the scope of the project, reflecting a focused, community based goal to bring a store into a new shopping center project. The project was not designed to do more than that it did. From the singular perspective of retail intervention and food access, Kansas City’s efforts are not impressive. Yet Kansas City’s TIF outcomes were not limited to grocery 
stores. A recurring theme emerging from the Kansas City case study is that TIF is not the most effective or expeditious way to bring a store into an underserved area.

Policy Feature 6: Cost-effectiveness

\begin{tabular}{|c|c|c|c|c|}
\hline Liberty City & $\begin{array}{l}\text { Pennsylvania's } \\
\text { Fresh Food } \\
\text { Financing Initiative }\end{array}$ & $\begin{array}{l}\text { Illinois Fresh Food } \\
\text { Fund \& Chicago } \\
\text { Efforts }\end{array}$ & $\begin{array}{l}\text { New Orleans Fresh } \\
\text { Food Retailer } \\
\text { Initiative }\end{array}$ & Kansas City Efforts \\
\hline $\begin{array}{l}\text { When compared to } \\
\text { the wasted business } \\
\text { investments of } \$ 7 \\
\text { million and the tens } \\
\text { of millions of federal } \\
\text { dollars wasted, } \$ 2.1 \\
\text { million spent to } \\
\text { create a successful } \\
\text { shopping center } \\
\text { with a grocery store } \\
\text { seems like a bargain. }\end{array}$ & $\begin{array}{l}\text { Considering the } \\
\text { costs of } \$ 195 \text { million } \\
(30+165) \text { initial } \\
\text { investments, the } \\
\text { SROI of } \$ 2.23 \text { billion } \\
\text { plus } 88 \text { stores plus } \\
5000+\text { jobs, the } \\
\text { benefits clearly } \\
\text { outweigh the costs. }\end{array}$ & $\begin{array}{l}\text { Ill. FFF - There is not } \\
\text { enough information } \\
\text { to determine this. } \\
\text { Chicago: There is } \\
\text { not enough } \\
\text { information to } \\
\text { determine this. }\end{array}$ & $\begin{array}{l}\text { If it cost FFRI } \\
\$ 117,000 \text { to get a } \\
\text { store open that will } \\
\text { serve Central City } \\
\text { and create } 8 \text { jobs, } \\
\text { then the benefits } \\
\text { will far exceed the } \\
\text { costs. }\end{array}$ & $\begin{array}{l}\text { Without better } \\
\text { transparency of } \\
\text { reports, this can't be } \\
\text { assessed. }\end{array}$ \\
\hline
\end{tabular}

Information on costs was not consistently available for all the case studies. When factoring in social costs such as health care, FFFI demonstrated a return on investment that reached beyond the opening of the stores and jobs created. Cost-effectiveness presents another way of thinking about impact and outcomes. FFFI's benefits of \$2.23 billion in SROI (social return on investment), plus 88 stores, and over 5000 jobs outweigh the costs of $\$ 195$ million. The New Orleans FFRI has shown a great start with an investment of $\$ 117,000$, which will yield a store that will bring fresh produce, seafood, and eight new jobs to a severely distressed area of the city. This first funded project bodes well for future FFRI endeavors. 
Policy Feature 7: Repeatability

\begin{tabular}{|c|c|c|c|c|}
\hline Liberty City & $\begin{array}{l}\text { Pennsylvania's } \\
\text { Fresh Food } \\
\text { Financing Initiative }\end{array}$ & $\begin{array}{l}\text { Illinois Fresh Food } \\
\text { Fund \& Chicago } \\
\text { Efforts }\end{array}$ & $\begin{array}{l}\text { New Orleans Fresh } \\
\text { Food Retailer } \\
\text { Initiative }\end{array}$ & Kansas City Efforts \\
\hline $\begin{array}{l}\text { This may be a } \\
\text { difficult case to } \\
\text { replicate. A } \\
\text { community would } \\
\text { need a strong } \\
\text { willed, visionary } \\
\text { leader. It would } \\
\text { need a CDC that } \\
\text { was interested in } \\
\text { supermarkets. The } \\
\text { leader and the CDC } \\
\text { would need to be } \\
\text { able to secure } \\
\text { partnered } \\
\text { investments from } \\
\text { public and private } \\
\text { sources. }\end{array}$ & $\begin{array}{l}\text { If a city has a non- } \\
\text { profit group with } \\
\text { strong community } \\
\text { ties and persuasive } \\
\text { advocacy, some } \\
\text { seed investment } \\
\text { funds, and a } \\
\text { capable CDFI, then a } \\
\text { similar FFFI would } \\
\text { be feasible. }\end{array}$ & $\begin{array}{l}\text { III. FFF - This initiative } \\
\text { failed to enlist a local } \\
\text { nonprofit/community- } \\
\text { based advocacy group } \\
\text { to the lead, from } \\
\text { initiation phase to } \\
\text { identification of } \\
\text { communities in need. } \\
\text { Also, a CDFI was not } \\
\text { contracted to manage } \\
\text { the program or help } \\
\text { grow funding. A state } \\
\text { wanting to implement } \\
\text { a similar program } \\
\text { would need to include } \\
\text { both agents. } \\
\text { Chicago: There is no } \\
\text { clear initiative to } \\
\text { repeat. Other cities } \\
\text { could perhaps study } \\
\text { how Chicago has tried } \\
\text { to make it easier for } \\
\text { large grocery retailers } \\
\text { to open stores. }\end{array}$ & $\begin{array}{l}\text { This program could } \\
\text { be repeated } \\
\text { elsewhere if there } \\
\text { were active } \\
\text { participation of the } \\
\text { state, funds obtain } \\
\text { either federally or } \\
\text { from the state, a } \\
\text { food-access savvy } \\
\text { non-profit to help } \\
\text { administer the } \\
\text { program, and a } \\
\text { highly capable CDFI } \\
\text { to handle financing. }\end{array}$ & $\begin{array}{l}\text { The success of using } \\
\text { a TIF plan to } \\
\text { develop a } \\
\text { supermarket would } \\
\text { depend on many } \\
\text { factors, such as the } \\
\text { condition of the } \\
\text { proposed site, the } \\
\text { capabilities of the } \\
\text { CDC backing the TIF } \\
\text { proposal, the } \\
\text { capability of local } \\
\text { incomes to support } \\
\text { a store, the } \\
\text { potential concerns } \\
\text { that a grocery } \\
\text { operator may have } \\
\text { in opening in an } \\
\text { urban area, to name } \\
\text { a few. If these and } \\
\text { other challenges } \\
\text { could be addressed, } \\
\text { then a TIF backed } \\
\text { grocery store } \\
\text { project could be } \\
\text { repeated } \\
\text { elsewhere. }\end{array}$ \\
\hline
\end{tabular}

FFFI provides the best retail intervention policy for repeatability. This is not simply because FFFI has the most demonstrable successful outcomes. FFFI has identifiable policy characteristics than can be studied, observed, modeled, and repeated. There are identifiable steps that can be taken to introduce the policy, build consensus, enact the policy, allocate funds, and administer projects. FFFI also demonstrated the importance of having key agents that can implement the policy and carry out projects. Finally, evidence of FFFI's repeatability can be found where similar policies have been created, such as the State of New York or the City of New Orleans. The Illinois Fresh Food Fund is also modeled on FFFI, but thus far it has not been demonstrated successful repeatability. Reasons for success or failure of repeatability will be discussed in further detail in the next section.

The Liberty City, Chicago, and Kansas City cases do not offer good examples of retail intervention policies that can be easily understood and replicated in other cities and states. Liberty City was primarily a one-time project that happened due to the efforts of one individual and his ability to forge 
the necessary public-private funding partnerships. No funding initiative was established for other projects. While it makes for good city press, the planned opening of many stores in Chicago does not reflect a coherent policy so much as the assertive efforts of private companies motivated by market expansion and their fortunate timing in finding receptivity with city administrators. The TIF plans used in Kansas City were based on local revitalization and redevelopment plans. TIF projects without grocery stores can be complicated enough and take a long time to implement. The next section will discuss in greater detail some of the particular weaknesses that make TIF difficult to apply toward retail intervention and grocery store projects.

\section{Overall Comparisons}

One approach to summing up the five case-study comparisons is to rank the policies. The ranking serves as an aggregate of the seven policy features. Though the Illinois Fresh Food Fund and the corporation-initiated efforts in Chicago were both discussed in the same case study section, they are ranked separately here.

\section{Ranking of Policy Efforts}

\begin{tabular}{|c|l|}
\hline Rank & Policy \\
\hline 1 & Pennsylvania’s FFFI \\
\hline 2 & New Orleans' FFRI \\
\hline 3 & Chicago's Corporation-initiated Efforts \\
\hline 4 & Kansas City’s TIFs \\
\hline 5 & Liberty City’s Community-based Effort \\
\hline 6 & Illinois Fresh Food Fund \\
\hline
\end{tabular}

Topping the list, FFFI paved the way, setting the standard for food access and retail intervention policies, and has had the greatest impact. A child of FFFI, New Orleans’ FFRI is ranked second for its rapid creation and implementation in response to post-Katrina and food desert conditions (New Orleans has been rated as the city with the worst food desert problem in the country). The third and fourth rankings are very close for different reasons. Chicago's corporation-initiated efforts (those of Wal-Mart, Walgreens, and Supervalu) may not fit neatly under an identifiable policy, but the plan for 36 stores to open would do a lot for Chicago, which is rated as the second worst American city for food deserts (Thomas, 2011). Kansas City’s TIFs rank fourth because, even if not the most expeditious and efficient of policies, TIF plans can bring stores into underserved areas. Though it was an important achievement for Otis Pitts, the Liberty City community-based effort did not result in a repeatable policy model and is 
therefore ranked fifth. Also a child of FFFI, the Illinois Fresh Food Fund was orphaned and at present, leading nowhere, which has earned it the sixth and lowest ranking.

\section{Effectiveness}

The previous comparison section primarily addressed the mechanics of the case study policies worked. This section considers why some policies worked well and others did not. In particular, the discussion will consider the TIF and FFFI policy models. Several weaknesses make the TIF model the least effective as a retail intervention policy. FFFI has proven effectiveness, but the model must be followed if successes are to be replicated.

\section{TIF Weaknesses}

Though TIFs can be somewhat flexible in changing tax structures to help finance development projects, TIFs have many weaknesses that make the policy model less than ideal for supermarket and grocery store projects. TIFs do not cover up-front development costs and this means that funding needs to come from some other source. TIF revenues come later, spread out over many years as increased property taxes (increments) or PILOTS (payment in lieu of taxes), which can result in too few revenues to cover original costs (Minnesota House of Representatives House Research, 2009). For a prospective store operator looking for assistance to defray opening costs, a TIF may not provide enough incentive. If a store project has been pre-financed through municipal bonds with the expectation of repayment through TIF generated revenues, then a city could be left holding the bag if for some reason the store operator does not come through (Ryan, 1986). TIFs also tend to be more costly than other forms of financing and can lead to higher tax rates for the community (Royse, 1992). If project TIF revenues are off (there is no guarantee a TIF will generate revenue), then this would mean a community was disrupted for the sake of financial insolvency. All of these disadvantages pose risks for any TIF projects, with or without supermarkets.

As TIF plans are prepared, estimated revenues are based on projected increases in property values. While this formula may be applicable to housing based projects, it is not the best way to assess the potential for a proposed supermarket to succeed. In making the case for supermarket profitability in Philadelphia, Johnson-Piett and colleagues (n.d.) used incomes rather property taxes to demonstrate concentrations of buying power in underserved neighborhoods. Further, they showed retail leakage from low income neighborhoods, which amounted to hundreds of millions of dollars being spent outside those neighborhoods on food. If the TIF plans for Blue Parkway and 39th and Prospect had used market analyses based on concentrated buying power, there might not have been such lengthy delays in getting stores to commit. As it stands, TIFs are the redevelopment tool Kansas City knows best. But unless TIFs 
are redesigned to match the markets of the supermarket and grocery store industry, TIF will most likely prove to be a cumbersome, time-consuming, and even risky form of retail intervention policy.

The FFFI Model and the Importance of CDFIs

For a policy following the FFFI model to be effective, it must at minimum have the following three components: a food-access advocacy group, start-up funds, and a CDFI (community development financial institution). The advocacy group, such as The Food Trust, must understand the community, have the ability to conduct locally based research and produce reports, work to build consensus, and lead the way toward policy creation and implementation. Start-up funds are also important can come in the form of state seed money or federal grants. Finally, the model requires a CDFI that understands the grocery/supermarket industry, has the ability to leverage assets to grow funds, and the capacity to manage complex loan and grant programs designed for supermarket development. Because the role of CDFIs is crucial to successful policies, the analysis will expand on the definition, functions, and roles CDFIs play in retail intervention policies.

Opening a supermarket in an urban area entails higher costs due to a number of factors such as land availability and costs, greater financial risks, and store security. These higher costs are the primary barrier for many supermarket operators, and without up-front funding to defray initial development, building, and opening costs, these stores will not enter urban communities. TIFs do not provide these upfront costs and, by extension, the barriers to store entry are not removed. CDFIs remove barriers of entry by providing direct grants and loans to supermarkets. The capabilities of a CDFI to grow the funds can help to expand and sustain the policy’s development programs.

In a 2004 study, Benjamin and colleagues described the objective of CDFIs and chronicled their history, summarized here. CDFIs provide a variety of financial services, funding, and technical assistance typically in housing and home financing in underserved communities. They are different from regular financial institutions (such as banks) in that credit is made available with lower interest rates, and loans will be made in areas known for higher risk of loan default. CDFIs often provide technical assistance, education, and training regarding home loans (to help reduce risk of defaulting on loans) and other forms of technical assistance and service. CDFIs are a continuance of the 1977 Community Development Act whose aim is to make development funding available for communities. CDFIs developed in part as a result of the growth and expansion of the financial industry in the 1990s. In 1994, the Community Development Financing Institute fund was established under the auspices of the U.S. Treasury department. As with most other community development related entities, such as CDCs and LISC, CDFIs have initially focused on financing for housing development and home ownership for people in underserved communities. To qualify as a CDFI and be eligible to receive funding from the CDFI fund, a 
financial institution must meet a set of criteria, including specialization in serving distressed communities and underserved people (U.S. Department of the Treasury, 2012).

To be effective in financing supermarket developments and, more important, to be able to sustain a retail intervention policy beyond a one-time project, a CDFI needs to understand the supermarket and grocery industry. Pennsylvania’s FFFI has a capable CDFI in The Reinvestment Fund, and New Orleans' FFRI has the Hope Enterprise Corporation. Both of these CDFIs are equipped to meet the financing needs of supermarket projects. For CDFIs that need to develop the capacity to work with the supermarket and grocery industry, the Reinvestment Fund has published Understanding the Grocery Industry (2011) which defines everything from grocery industry store formats (such as traditional supermarkets and limited assortment supermarkets), to pricing structures, and cost controls. A more technical guide, Underwriting Supermarkets \& Grocery Stores (The Reinvestment Fund, 2011) provided detailed quantitative measures (such as Gross Margins, which provide a measure of a store's product mix and operational efficiency) that a CDFI can use to assess the profitability and potential success of a proposed store project.

In addition to efficacy in supermarket financing, CDFIs need to be able to leverage funds to expand the available funding. Through investments and partnerships with other financial institutions, The Reinvestment Fund was able to take the \$30 million Pennsylvania state seed money and expand it funds to $\$ 165$ million. The Hope Enterprise Corporation in New Orleans was able to provide a $100 \%$ match to the $\$ 7$ million of Community Block Development Grant Funds. Growth of funds is essential to sustaining a food financing initiative.

The importance of a CDFI in the financial operations of a food financing initiative cannot be overstated. Without The Reinvestment Fund, Pennsylvania's FFFI would not have been able to support the financing of 88 new stores. Without the Hope Enterprise Corporation, New Orleans' FFRI would not have gotten off the ground. One of the main reasons for the Illinois Fresh Food Fund's lack of success is that a CDFI has not been identified. As long as there is no CDFI on board, the $\$ 10$ million in state seed money will never be allocated. A CDFI is needed to leverage the money so that program funds can be expanded. If the funds are not increased, then even if the \$10 million were made available to store projects, the funds would not last long and the Illinois Fresh Food Fund would not be sustainable.

\section{Conclusions Drawn from Policy Analysis}

This analysis does not suggest that supermarkets and grocery stores are the best or only solution for underserved urban areas. Depending on the needs and the buying power of communities, other alternatives such as small corner stores, urban agriculture, CSAs, farmers’ markets, food coops, 
community gardens, shared backyard gardens, and squatter/guerilla gardens may provide more effective food-access solutions. This study has not answered all the questions surrounding food-access issues plaguing underserved areas. What this study has done is to draw from specific instances of policy efforts and direct attention to strengths and weaknesses.

Under the broad topic of "retail intervention policies", this analysis has considered the merits of various policy models used to bring grocery stores and supermarkets into food deserts. One reason for this choice is that, by in large, the U.S. food system distributes food to consumers primarily through grocery stores and supermarkets. Grocery stores and supermarkets account for the greatest volume of food distribution. Also, as the case studies made evident, public policy has been attempting to address food access issues in underserved areas for well over ten years. No one-size-fits-all solutions have been developed that can be easily mimicked and followed nationwide.

Of the various iterations of retail intervention policies, some have clearly worked better than others. In the case of Chicago, corporation-initiated efforts to open stores do not present examples of actual retail intervention policy so much as market expansion. The evidence from the case studies indicates that policies specifically designed for financing food-access projects, such as FFFI, are more effective and have greater impact than policies, such as TIF, that are not designed expressly for foodaccess project financing. This analysis has also demonstrated that a previously successful policy model can be poorly replicated if key policy components-a food-access advocacy group, start-up funding, and a CDFI-are not in place. The opportunities for further research of retail intervention policies are vast, and the hope is that this analysis can provide a useful starting point for further studies as well as efforts towards retail intervention policy creation. 


\section{Sources}

4VF News - Daily News Channel. (2008). Building on rock, not sand: Riots in Liberty City, Florida. Retrieved from http://www.4vf.net/building-on-rock-not-sand-riots-in-liberty-city-florida/.

39th \& Prospect Tax Increment Financing Plan Kansas City, Missouri. (2006). Retrieved from http://edckc.com/docs/TIF/Plans/39th_and_Prospect/00079720.PDF.

Allen, J. L. (1994, February 13). Developer feels at liberty in inner city. Chicago Tribune. Retrieved from http://articles.chicagotribune.com/1994-02-13/business/9402130080_1 liberty-city-tacolcy-economicdevelopment-corp-riots

American Farmland Trust. (n.d.). Farm and food voices: Will the windy city become the greenest city with the healthiest people? Retrieved from http://www.farmland.org/programs/campaign/RichardM.Daley.asp

Bell, J., \& Standish, M. (2009). Building healthy communities through equitable food access. Federal Reserve Bank of San Francisco Publications: Community Development Investment Review, 5(3), 75-87. Retrieved from http://www.frbsf.org/publications/community/review/vol5 issue3/bell_standish.pdf

Benjamin, L., Rubin, J. S., \& Zielenbach, S. (2004). Community development financial institutions: Expanding access to capital in under-served markets. In J. DeFilippis \& S. Saegert (Eds.), The Community Development Reader. New York: Routledge.

Bitler, M., \& Halder, S. J. (2011). An economic view of food deserts in the United States. Journal of Policy Analysis and Management, 30(1), 153-176. DOI: 10.1002/pam.20550.

Bloyd, J., Braun, J., Williams, O., \& Kelly, R. (2011, November 1). A strategic assessment of the Illinois Fresh Food Fund: Working towards an ideal national initiative [[PowerPoint slides]. 139th Annual Meeting of the American Public Health Association, Washington DC. Retrieved from http://www.slideshare.net/jimbloydmph/a-strategic-assessment-of-the-illinois-fresh-food-fund

Bluford, J. (2011, November 9). Traversing the food deserts of Kansas City. Truman Medical Centers Blog. Retrieved from http://blog.trumed.org/2011/11/traversing-the-food-deserts-of-kansas-city/. 
Booth, W. (1992, June 5). Miami community's progress suggests riots' scars heal from within. The Washington Post. Retrieved from LexisNexis.

Brush Creek Corridor Tax Increment Financing Plan. (1999). Retrieved from http://edckc.com/docs/TIF/Plans/Brush Creek Corridor/00031131.PDF

Burton, H., \& Perry, D. (2004). Stimulating supermarket development: A new day for Philadelphia. Retrieved from http://www.thefoodtrust.org/pdf/SupermktReport_F.pdf

Byfield-Green, L. (2011, July 29). Analysis - Walmart joins US grocers opening in 'food deserts'. Retail Week. Retrieved from LexisNexis.

Central City Funders’ Collective (CCFC). (2012, January 10). Startup grocer gets fresh-food loan. Retrieved from http://ccfcnola.org/startup-grocer-gets-fresh-food-loan/

Chirouze, N. A., Atlas, J., \& Rajaruru, P. (2010). The Food Trust and the Fresh Food Financing Initiative: Eliminating “food deserts.” Philadelphia Social Innovations Journal, 3, 1-10. Retrieved from http://www.philasocialinnovations.org/site/index.php?option=com_content\&view=article\&id=177:thefood-trust-and-the-fresh-food-financing-initiative-eliminating-food-deserts\&catid=21:featured-socialinnovations\&Itemid $=35$

“City announces plans to construct grocery store at $39^{\text {th }}$ and Prospect.” (2011, November 3). Targeted News Service. Retrieved from LexisNexis.

“City Council actions.” (2005, September 21). The Kansas City Star. Retrieved from LexisNexis.

City of Chicago. (2011, October 25). Mayor Emanuel announces three dozen new and expanded grocery stores in communities across Chicago, creating more than 2000 jobs and reducing "food desert” acreage in low-income communities by $20 \%$ [Press release]. Retrieved from http://www.cityofchicago.org/content/city/en/depts/mayor/press_room/press_releases/2011/october_2011/ mayor_emanuel_announcesthreedozennewandexpandedgrocerystoresinco.html 
City of Kansas City. (2011, November 3). City announces plans to construct grocery store at 39th and Prospect. News from City Hall [Press release]. Retrieved from http://www.kcmo.org/CKCMO/NewsArchives/NewsArchives-2011/110311A

City of Kansas City. (2012, April 5). 39th and Prospect ALDI construction moves ahead with Super TIF approval. News from City Hall [Unpublished press release].

Cummins, S., \& Macintyre, S. (2002). “Food deserts”-evidence and assumption in health policy making. BMJ, 325, 436-38. DOI: 10.1136/bmj.325.7361.436.

DeFilippis, J., \& Saegert, S. (2008). The community development reader. New York: Routledge.

Economic Development Corporation of Kansas City. (n.d.). Tax Increment Financing Commission. Retrieved from http://edckc.com/agencies-partners/tax-increment-financing-commission/.

Eng, M. (2011, September 28). Food entrepreneurs grow sweet on Emanuel. Chicago Tribune. Retrieved from http://articles.chicagotribune.com/2011-09-28/news/ct-met-chicago-food-policies-

20110928_1_food-trucks-matt-maroni-food-carts

Evans, D. (2010, March 4). Budget briefing: Report on key issues from the House Appropriations Committee. Pennsylvania Fresh Food Financing Initiative. Retrieved from http://www.ncsl.org/documents/labor/workingfamilies/PA_FFFI.pdf

Ferrell, K. (2012, January 11). Truman Medical Center to build oasis in urban “food desert.” Fox4KC. Retrieved from http://fox4kc.com/2012/01/11/truman-medical-center-to-build-oasis-in-urban-food-desert/

Gallagher, M. (2010). From food desert to food oasis: Blueprint for change in Chicago. Chicago, IL: Mari Gallagher Research \& Consulting Group. Retrieved from http://www.marigallagher.com/site media/dynamic/project files/FoodDesert to Oasis.pdf

Gallagher, M. (2011). The Chicago food desert drilldown. Chicago, IL: Mari Gallagher Research \& Consulting Group. Retrieved from http://marigallagher.com/site_media/dynamic/project_files/Final_2011_ChgFD_drilldown.pdf 
Giang, T., Karpyn, A., Burton Laurison, H., Hillier, A., \& Perry, R. D. (2008). Closing the grocery gap in underserved communities: The creation of the Pennsylvania Fresh Food Financing Initiative. Public Health Management Practice, 14(3), 272-279.

Grogan, P. (1992, May 14). Liberty City’s lessons for L.A. St. Petersburg Times. Times Publishing Company. Florida. Retrieved from LexisNexis.

Hamm, M. W., \& Baron, M. (1999). Developing an integrated sustainable urban food system: The case of New Jersey, United States. In M. Koc \& R. MacRae (Eds.)., Hunger proof cities: Sustainable urban food systems (177-181). Ottawa, ON, Canada: International Development Research Center.

Harries, C., Holtzman, E., Lang, B. \& Perry, D. (2009). Stimulating supermarket development in Illinois: Healthier people, healthier communities \& a healthier economy. Philadelphia, PA: The Food Trust. Retrieved from http://www.ildceo.net/NR/rdonlyres/1C40652A-90FD-4606-823A68B786463273/0/ilreport.pdf.

Heinzmann, D. (2011, October 25). Emanuel steps up battle against city's 'food deserts'. Chicago Tribune. Retrieved from http://articles.chicagotribune.com/2011-10-25/news/ct-met-emanuel-food-desert20111025_1_food-deserts-mari-gallagher-stores-in-underserved-areas.

Hope Enterprise Corporation. (2011). New Orleans Fresh Food Retailer Initiative. Retrieved from http://www.hope-ec.org/index.php?option=com_content\&view=article\&id=135\&Itemid=203

Hospital Hill Economic Development Corporation. (n.d.). Grocery and market. Retrieved from http://www.hhedc.com/About.aspx.

Huber, B. (2011, September 14). Walmart’s fresh food makeover. The Nation. Retrieved from http://www.thenation.com/article/163396/walmarts-fresh-food-makeover

Illinois Advisory Committee to the U.S. Commission on Civil Rights. (2011, October). Food deserts in Chicago. A Report of the Illinois Advisory Committee to the United States Commission on Civil Rights. Retrieved from http://www.usccr.gov/pubs/IL-FoodDeserts-2011.pdf 
Johnson, C. L. (2002). Tax Increment Financing (TIF). National Association of Realtors. Boston, MA:

Robinson \& Cole LLP. Retrieved from

http://www.realtor.org/smart growth.nsf/docfiles/tifreport.pdf/\$file/tifreport.pdf

Johnson-Piett, J., Perry, D., Buron, H., \& Adler, D. (n.d.). Philadelphia’s new markets: Ripe opportunities for retailers (special report). Philadelphia, PA: The Food Trust. Retrieved from http://www.thefoodtrust.org/pdf/PNM\%20Report\%20Final.pdf

Jones, S. M. (2011, July 27). Chicago's first of 5 expected Walmart Express locations to open Wednesday. Chicago Tribune. Retrieved from http://articles.chicagotribune.com/2011-07-27/business/ctbiz-0727-walmart-express-20110727_1_wal-mart-stores-walmart-express-walmart-supercenter

“Kansas City Council action.” (1992, February 10). The Kansas City Star, B2.

Koc, M., \& MacRae, R. (1999). For hunger proof cities: Sustainable urban food systems. Ottawa, ON, Canada: International Development Research Center.

Lee, G., \& Lim, H. (2009). A spatial statistical approach to identifying areas with poor access to grocery foods in the city of Buffalo, New York. Urban Studies, 46, 1299. DOI: 10.1177/0042098009104567.

Leete, L., Bania, N., \& Sparks-Ibanga, A. (2011). Congruence and coverage: Alternative approaches to identifying urban food deserts and food hinterlands. Journal of Planning Education and Research, XX(X), 1-15. DOI: 10.1177/0739456X11427145.

LifeCity. (2011). Mayor launches program to expand fresh food access and grocery stores in under-served neighborhoods [Press release]. Retrieved from http://mylifecity.com/news/detail/26/Press-ReleaseMayor-launches-program-to-expand-fresh-food-access-and-grocery-stores-in-under-servedneighborhoods.

Manta. (2012). Company profile: Blue Parkway Sun Fresh, Inc. Retrieved April 6, 2012, from http://www.manta.com/c/mmy9hwk/blue-parkway-sunfresh-inc.

"Mayor Landrieu and the City Council announce first Fresh Food Retailer Initiative loan." (2011, December 22). Targeted News Service. Retrieved April 3, 2012, from LexisNexis Academic. 
Minnesota House of Representatives House Research. (2009). How TIF works: Basic mechanics. Retrieved from http://www.house.leg.state.mn.us/hrd/issinfo/tifmech.htm

Myers, B. (2011, March 24). City of New Orleans spending \$7M to bring groceries to its 'food deserts'. New Orleans City Business. Retrieved April 3, 2012, from LexisNexis Academic.

New Rules Project. (n.d.). Pennsylvania Fresh Food Financing Initiative. Retrieved from http://www.newrules.org/retail/rules/financing-local-businesses/pennsylvania-fresh-food-financinginitiative.

Oberholtz, C., \& Lee, B. (2012, January 11). Hospital plans to eliminate food desert in KC. KCTV5. Retrieved from http://www.kctv5.com/story/16495481/hospital-plans-to-eliminate-a-food-desert-in-kc.

O’Connor, A. (2008). Swimming against the tide: A brief history of federal policy in poor communities. In J. DeFilippis \& S. Saegert (Eds.), The Community Development Reader. New York: Routledge

O'Connor, P. (2009, May 19). Illinois Food Marketing Task Force calls for establishment of 'Illinois Fresh Food... [Press release]. Illinois Food Marketing Task Force. Retrieved from http://www.reuters.com/article/2009/05/19/idUS186392+19-May-2009+PRN20090519

Office of Management and Budget. (2012). An economy built to last for our cities and metropolitan areas. Retrieved from http://www.whitehouse.gov/omb/factsheet/an-economy-built-to-last-for-our-cities-andmetropolitan-areas.

Perry, D. (2001). The need for more supermarkets in Philadelphia (special report). Philadelphia, PA: The Food Trust.

Perry, D., Harries, C., \& Goldblatt, D. (2008). The need for more supermarkets in Chicago (special report). Philadelphia, PA: The Food Trust. Retrieved from http://www.thefoodtrust.org/pdf/SupermarketsChicago.pdf 
Pierce, N. R. (1985, April 14). Supermarket just a first step in Liberty City’s revival formula. Orlando Sentinel. Retrieved from http://articles.orlandosentinel.com/1985-04-14/news/0290130237_1_libertycity-economic-development-city-revival.

PolicyLink. (2012). Federal budget process. Improving access to healthy food. Oakland, CA: PolicyLink. Retrieved from http://www.policylink.org/site/c.lkIXLbMNJrE/b.7086325/k.5047/Federal_Budget_Process.htm

PolicyLink \& Local Initiatives Support Corporation. (2008). Grocery store attraction strategies: A resource guide for community activists and local governments. Oakland, CA: PolicyLink. Retrieved from http://www.policylink.org/atf/cf/\%7B97C6D565-BB43-406D-A6D5-

ECA3BBF35AF0\%7D/groceryattraction final.pdf.

Pothukuchi, K. (2005). Attracting supermarkets to inner-city neighborhoods: Economic development outside the box. Economic Development Quarterly, 19, 232-244. DOI: 10.1177/0891242404273517.

Raja, S., Ma, C., \& Yadav, P. (2008). Beyond food deserts: Measuring and mapping racial disparities in neighborhood food environments. Journal of Planning Education and Research, 27, 469. DOI: 10.1177/0739456X08317461.

Rose, D., Bodor, J. N., \& Swalm, C. M. (2009). Deserts in New Orleans? Illustrations of urban food access and implications for policy. University of Michigan National Poverty Center/USDA Economic Research Service Research, "Understanding the Economic Concepts and Characteristics of Food Access." Retrieved from http://www.npc.umich.edu/news/events/food-access/rose et al.pdf

Royse, M. (1992). Advantages and disadvantages of tax increment financing. Economic Development Review, 10(2), 84.

Ryan, G. H. (1986, May). Tax increment financing as a local government development policy. Illinois Municipal Review, p. 8. Retrieved from http://www.lib.niu.edu/1986/im860507.html.

Stevens, C. (2009, October 16). State of Louisiana approves \$7 million for fresh food initiative in New Orleans. Market Makeovers. Retrieved from http://www.marketmakeovers.org/news/story/state-oflouisiana-approves-7-million-for-fresh-food-initiative-in-new-orleans. 
Swope Community Enterprises. (2004). Swope Community Enterprises Annual Report 2004. Kansas City, MO. Retrieved from: http://www.swopeparkwayhc.org/Media/Swope Enterprises_Annual Reports.aspx.

Swope Community Enterprises. (2006). Swope Community Enterprises Annual Report 2006. Kansas City, MO. Retrieved from: http://www.swopeparkwayhc.org/Media/Swope Enterprises Annual Reports.aspx.

Swope Community Enterprises. (2007). Swope Community Enterprises Annual Report 2007. Kansas City, MO. Retrieved from: http://www.swopeparkwayhc.org/Media/Swope_Enterprises_Annual_Reports.aspx.

The Food Trust. (2004). Pennsylvania Fresh Food Financing Initiative: Encouraging the development of food retail in underserved Pennsylvania communities. Philadelphia, PA: The Food Trust. Retrieved from http://www.thefoodtrust.org/php/programs/fffi.php

The Food Trust. (2005). Supermarket campaign in Illinois: The creation of the Illinois Food Marketing Task Force and the Illinois Fresh Food Fund. Philadelphia, PA: The Food Trust. Retrieved from: http://www.thefoodtrust.org/php/programs/supermarket-IL.php

The Food Trust. (2009). In the news: State of Louisiana approves $\$ 7$ million for fresh food initiative in New Orleans [Press release]. Philadelphia, PA: The Food Trust. Retrieved from http://www.thefoodtrust.org/php/press/news detail.php?id=104

The Reinvestment Fund. (2010) Pennsylvania Fresh Food Financing Initiative. Philadelphia, PA: The Reinvestment Fund. Retrieved from http://www.trfund.com/resource/downloads/Fresh_Food_Financing_Initiative_Comprehensive.pdf.

The Reinvestment Fund. (2011). Understanding the grocery industry. Philadelphia, PA: The Reinvestment Fund. Retrieved from http://www.cdfifund.gov/what we do/resources/Understanding\%20Grocery\%20Industry for\%20fund 1 02411.pdf.

The Reinvestment Fund. (2011). Underwriting supermarkets and grocery stores. Retrieved from http://www.cdfifund.gov/what_we_do/resources/Underwriting\%20supermarkets_for\%20Fund_102411.pd $\underline{f}$ 
The Reinvestment Fund. (2012). LSA mapping tool [Website]. Retrieved from http://www.trfund.com/TRF-LSA-widget.html.

The Shops on Blue Parkway. (2012). Website. Retrieved April 1, 2012, from http://www.theshopsonblueparkway.com/history.aspx.

Thomas, J. (2011, September 22). America’s worst 9 urban food deserts. News One. Retrieved from http://newsone.com/newsone-original/jothomas/americas-worst-9-urban-food-deserts/.

Truehaft, S., \& Karpyn, A. (2010). The grocery gap: Who has access to healthy food and why it matters. Oakland, CA: PolicyLink. Retrieved from http://www.policylink.org/atf/cf/\%7B97C6D565-BB43-406DA6D5-ECA3BBF35AF0\%7D/FINALGroceryGap.pdf.

United States Department of Agriculture (USDA). (2009, June). Access to affordable and nutritious food: Measuring and understanding food deserts and their consequences. Economic Research Service. Retrieved from http://www.ers.usda.gov/Publications/AP/AP036/.

United States Department of Agriculture (USDA). Economic Research Service. (n.d.). Food environment atlas. Retrieved from http://www.ers.usda.gov/FoodAtlas/.

United States Department of Agriculture (USDA). Economic Research Service. (n.d.). Food desert locator. Retrieved from http://www.ers.usda.gov/data/foodDesert/.

United States Department of Health and Human Services (HHS). (2010). Obama administration details health food financing initiative. Retrieved from http://www.hhs.gov/news/press/2010pres/02/20100219a.html

United States Department of Health and Human Services (HHS). (2011). Health food financing initiative. Retrieved from http://www.acf.hhs.gov/programs/ocs/ocs food.html

United States Department of Health and Human Services (HHS). (2010). Obama administration details healthy food financing initiative. Retrieved from http://www.hhs.gov/news/press/2010pres/02/20100219a.html 
United States Department of the Treasury. (2012). CDFI certification: Frequently asked questions. Community Development Financial Institutions Fund. Retrieved from http://www.cdfifund.gov/docs/certification/cdfi/CDFIcertificationFAQs.pdf

United States Department of the Treasury. (2011). Financing health food options: Implementation handbook. A Food Systems Overview. Retrieved from http://www.cdfifund.gov/what_we_do/resources/Food\%20Systems\%20Overview\%20for\%20Fund\%2010 2411.pdf.

“U.S. aid to Miami said to fall short.” (1985, October 13). The New York Times, p. 37. Retrieved from LexisNexis.

Yaccino, S. (2011, October 25). In Chicago, Michelle Obama takes on food deserts. The Caucus Blog. The New York Times. Retrieved from http://thecaucus.blogs.nytimes.com/2011/10/25/in-chicagomichelle-obama-takes-on-food-deserts/. 